\title{
Final Report - Assessment of Testing Options for the NTR at the INL
}

Steven D. Howe

Travis McLing

Michael McCurry

Mitchell Plummer

February 2013

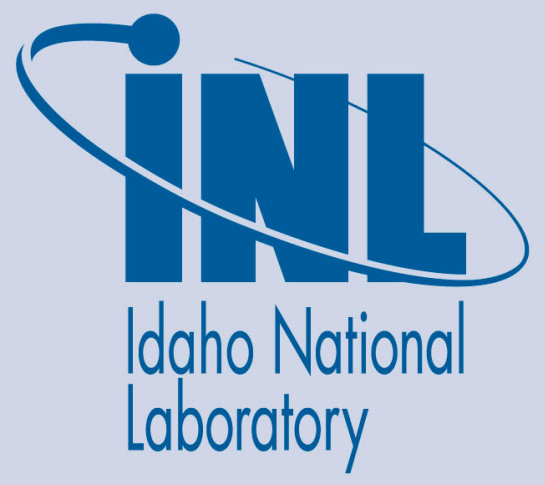

The INL is a U.S. Department of Energy National Laboratory operated by Battelle Energy Alliance 
INL/EXT-13-28526

\title{
Final Report - Assessment of Testing Options for the NTR at the INL
}

\author{
Steven D. Howe \\ Travis McLing \\ Michael McCurry \\ Mitchell Plummer
}

February 2013

Idaho National Laboratory
Idaho Falls, Idaho 83415

http://www.inl.gov

Prepared for the

U.S. Department of Energy

Office of Nuclear Energy

Under DOE Idaho Operations Office

Contract DE-AC07-05ID14517 


\section{Final Report - Assessment of Testing Options for the NTR at the INL}

Steven D. Howe, Travis McLing, Michael McCurry, Mitchell Plummer

\section{Executive Summary}

One of the main technologies that can be developed to dramatically enhance the human exploration of space is the nuclear thermal rocket (NTR). Several studies over the past thirty years have shown that the NTR can reduce the cost of a lunar outpost, reduce the risk of a human mission to Mars, enable fast transits for most missions throughout the solar system, and reduce the cost and time for robotic probes to deep space. Three separate committees of the National Research Council of the National Academy of Sciences have recommended that NASA develop the NTR. One of the primary issues in development of the NTR is the ability to verify a flight ready unit.

Three main methods can be used to validate safe operation of a NTR, after which a fully complete engine could be launched into orbit for the first full power test. The NTR testing options include

1) Full power, full duration test in an above ground facility that scrubs the rocket exhaust clean of any fission products;

2) Full power, full duration test using the Subsurface Active Filtering of Exhaust (SAFE) technique to capture the exhaust in subsurface strata;

3) Test of the reactor fuel at temperature and power density in a driver reactor with subsequent first test of the fully integrated NTR in space.

The first method, the above ground facility, has been studied in the past [Rocketdyne, INL, MSFC]. The second method, SAFE, has been examined for application at the Nevada Test Site. The third method relies on the fact that the Nuclear Furnace series of tests in 1971 showed that the radioactive exhaust coming from graphite based fuel for the NTR could be completely scrubbed of fission products and the clean hydrogen flared into the atmosphere. 
Under funding from the MSFC, the Center for Space Nuclear Research (CSNR) at the Idaho National laboratory (INL) has completed a reexamination of Methods 2 and 3 for implementation at the INL site. In short, the effort performed the following:

- Assess the geology of the INL site and determine a location suitable SAFE testing;

- Perform calculations of gas transport throughout the geology;

- Produce a cost estimate of a non-nuclear, sub-scale test using gas injection to validate the computational models;

- Produce a preliminary cost estimate to build a nuclear furnace equivalent facility to test NTR fuel on a green field location on the INL site.

Reexamination of Method 3, involving test of the reactor fuel in a driver reactor indicated that a new Category I facility would be required, which would cost in excess of $\$ 250 \mathrm{M}$. Reexamination of Method 2, showed that the INL geology is substantially better suited to the SAFE testing method than the NTS site. The existence of impermeable interbeds just above the sub-surface aquifer ensure that no material from the test, radioactive or not, can enter the water table. Similar beds located just below the surface will prevent any gaseous products from reaching the surface for dispersion. The extremely high permeability of the basalt strata between the interbeds should allow rapid dispersion of the rocket exhaust. In addition, the high permeability suggests that a lower back-pressure may develop in the hole against the rocket thrust, which increases safety of operations. Finally, the cost of performing a sub-scale, non-nuclear verification experiment was determined to be $\$ 2,100 \mathrm{~K}$ a significant savings over the NTS.

Based on the results of this study, a cost estimate for testing a nuclear rocket at the INL site appears to be warranted. Given the fact that a new nuclear fuel may be possible that does not release any fission products, the SAFE testing option appears to be the most affordable. 


\section{Introduction}

One of the main technologies that can be developed to dramatically enhance the human exploration of space is the nuclear thermal rocket (NTR). Several studies over the past thirty years [1-4] have shown that the NTR can reduce the cost of a lunar outpost, reduce the risk of a human mission to Mars, enable fast transits for most missions throughout the solar system, and reduce the cost and time for robotic probes to deep space. Three separate committees of the National Research Council [5-7] of the National Academy of Sciences have recommended that NASA develop the NTR. One of the primary issues in development of the NTR is the ability to verify a flight ready unit.

Three main methods can be used to validate safe operation of a NTR:

1) Full power, full duration test in an above ground facility that scrubs the rocket exhaust clean of any fission products;

2) Full power, full duration test using the Subsurface Active Filtering of Exhaust (SAFE) technique to capture the exhaust in subsurface strata;

3) Test of the reactor fuel at temperature and power density in a driver reactor with subsequent first test of the fully integrated NTR in space.

The first method, the above ground facility, has been studied in the past [Rocketdyne, INL, MSFC]. The primary barriers are the need for 1) large operations staff, 2) long term operation to maintain capability, and 3) generation of large masses of potentially radioactive waste from the filtration system. The previous studies estimated the cost of the test facility to be between $\$ 200$ $500 \mathrm{M}$ depending upon the specific size of the NTR. This cost was seen as an up-front expense before any testing could be achieved. Consequently, the method has been seen as a major obstacle in time of decreasing government budgets.

The second method, SAFE, has been examined for application at the Nevada Test Site [Howe 99, DRI 2007, Howe 2009-11]. The results of these studies showed that an eight foot diameter hole around 1200 feet deep at the NTS would produce a back pressure on the rocket of around 35 psig. The results indicate that any size engine could be operated for any length of time unlike Method 1 which had to operate at only one power level. The estimate of the cost for testing a NTR at NTS was $\$ 45 \mathrm{M}$. 
The third method relies on the fact that the Nuclear Furnace series of tests in 1971 showed that the radioactive exhaust coming from graphite based fuel for the NTR could be completely scrubbed of fission products and the clean hydrogen flared into the atmosphere. Conceptually, a similar system could be built today to qualify the NTR fuel performance. Then a fully complete engine would be launched into orbit for the first full power test.

Under funding from the MSFC, the Center for Space Nuclear Research (CSNR) at the Idaho National laboratory (INL) has completed a reexamination of Methods 2 and 3 for implementation at the INL site. In short, the effort performed the following:

- Assess the geology of the INL site and determine a location suitable SAFE testing;

- Perform calculations of gas transport for the INL stratigraphy;

- Produce a cost estimate of a non-nuclear, sub-scale test using gas injection to validate the computational models;

- Produce a preliminary cost estimate to build a nuclear furnace equivalent facility to test NTR fuel on a green field location on the INL site.

\section{SAFE Concept}

The basis of the SAFE concept relies on the porosity of sub-surface strata to transport the exhaust gases and to act as a filter. In essence, the concept proposes to put the nuclear rocket at the top of a hole that has been sealed as depicted in Figure 1. As the rocket fires the effluent into the hole, pressure will build. Eventually the pressure will reach a level where the amount of gas and water vapor driven into the porous rock equals the mass flow of the rocket. Consequently, for a porous matrix of great horizontal extent, the rocket can be operated for long periods over a relatively wide range of power levels. Thus, the requirements of the engine may be determined at a later stage in the program - as the constraints imposed by the capacity of the testing facility are not the primary limitation.

A set of calculations using the WAFE code to model the SAFE concept were made in 1999 [2003] for the NTS geology. WAFE is a 2-D model of water, water vapor and non-condensible gas flow and energy transport in permeable soil and rock materials. It was developed initially for the underground nuclear weapons testing program to estimate transient pressure, temperature, and water saturation changes in stemming columns and geologic units surrounding a hot pressurized cavity produced by a nuclear test. 
Those simulations modeled a vertical borehole with a diameter of $2.4 \mathrm{~m}$, extending to a depth of $360 \mathrm{~m}$, typical of emplacement holes at the NTS. The upper $30 \mathrm{~m}$ of the hole is lined with a steel casing. The earth surrounding the hole is alluvium, uniform in properties. Typical values for relevant properties of alluvium at the NTS are a porosity of $35 \%$, a permeability of 8 darcys, and initial pore water saturation of $30 \%$, at a temperature of $20^{\circ} \mathrm{C}$. Simulations start with injection of the exhaust gases $\left(\mathrm{H}_{2} \mathrm{O}\right.$ and $\left.\mathrm{H}_{2}\right)$ into the borehole at the bottom of the steel liner. Two cases were considered: $100 \%$ thrust, and $30 \%$ thrust. For the $100 \%$ thrust case, a total of $73.4 \mathrm{~kg} / \mathrm{s}$ of $\mathrm{H}_{2} \mathrm{O}(17.4 \mathrm{~kg} / \mathrm{s}$ from the engine exhaust plus $56 \mathrm{~kg} / \mathrm{s}$ of cooling spray) and $0.64 \mathrm{~kg} / \mathrm{s}$ of excess $\mathrm{H}_{2}$ were injected. For the $30 \%$ thrust case, a total of $20.5 \mathrm{~kg} / \mathrm{s}$ of $\mathrm{H}_{2} \mathrm{O}(4.9 \mathrm{~kg} / \mathrm{s}$ from the engine exhaust plus $15.6 \mathrm{~kg} / \mathrm{s}$ of cooling spray) and $0.33 \mathrm{~kg} / \mathrm{s}$ of excess $\mathrm{H}_{2}$ were injected. In both cases, injection temperature was assumed to be $600 \mathrm{C}$.

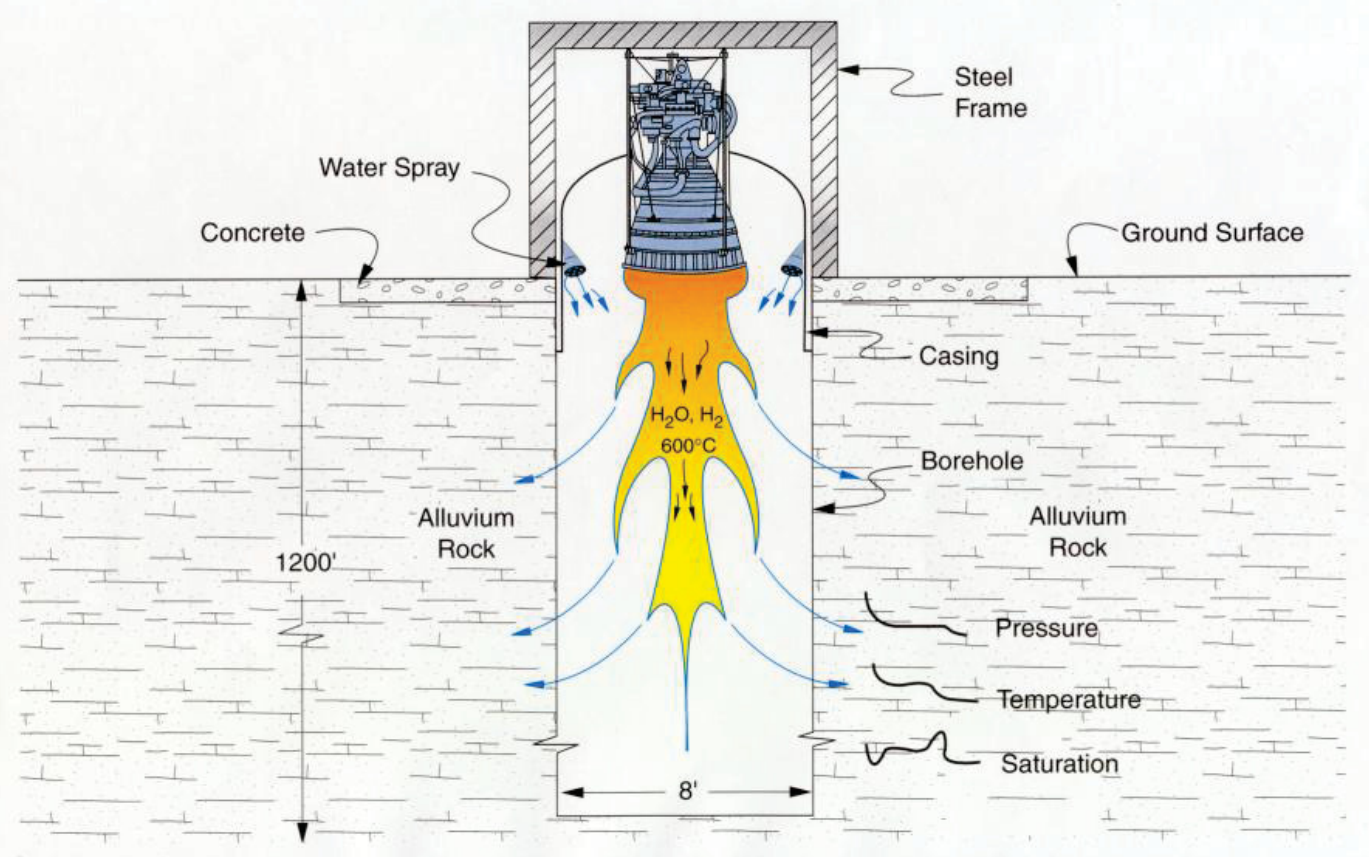

FIGURE 1. Artist's Concept of the SAFE Configuration.

The cooling spray added at the top of the borehole is a necessary feature; otherwise, borehole temperatures would be over $3000 \mathrm{C}$ and would damage or melt the steel casing and cause major chemical changes in the alluvium. Further, other simulations indicated that borehole pressure rise would be considerably higher without the water spray. 
Results of the simulations showed the pressure rise in the borehole at the mid-depth level. In both cases, the pressure rise exhibits an initial spike of a few psi, which subsides, followed by a more gradual rise. In the $100 \%$ thrust case, after 2 hours, the pressure has risen to about 36 psia, and to about 21 psia in the $30 \%$ thrust case. The rate of pressure increase is diminishing in both cases with time, as the rate of flow into the surrounding soil increases.

Cooper and Decker (2011) also conducted numerical simulations of the SAFE concept applied at the Nevada Test Site. Based on the permeability range of the stratigraphy there, they determined that a thickness of $100 \mathrm{~m}$ would be required to maintain a backpressure of less than their design criterion of $0.24 \mathrm{MPa}(35 \mathrm{psi}$ ) for the $30 \%$ thrust test case. In their simulation, the injected gas consisted of $14.5 \mathrm{~kg} \mathrm{~s}^{-1}$ hydrogen gas and $15 \mathrm{~kg} \mathrm{~s}^{-1}$ water vapor, with the hydrogen gas modeled as air. The results of those previous studies are used as comparison for the calculations in this study.

\section{Gas Transport Analysis}

To evaluate the potential for a successful SAFE test at the INL, we conducted gas transport calculations to assess how gas pressures in the vadose zone might respond to a hypothesized rocket exhaust injection test. The conceptual model considered in these calculations is based on a the typical stratigraphy of the vadose zone at the INL (Figure 2), that includes extensive horizontal layers of low-permeability sedimentary deposits separating extensive thicknesses of fractured basalt. In an NTR test at the INL, exhaust would be injected into the fractured basalt between sedimentary layers to limit exhaust flow to the surface or to the underlying aquifer. Detailed discussion of the geology of the site, constraints on possible locations for such a test, and maps of areas that meet the necessary criteria are included in a subsequent geology discussion. 


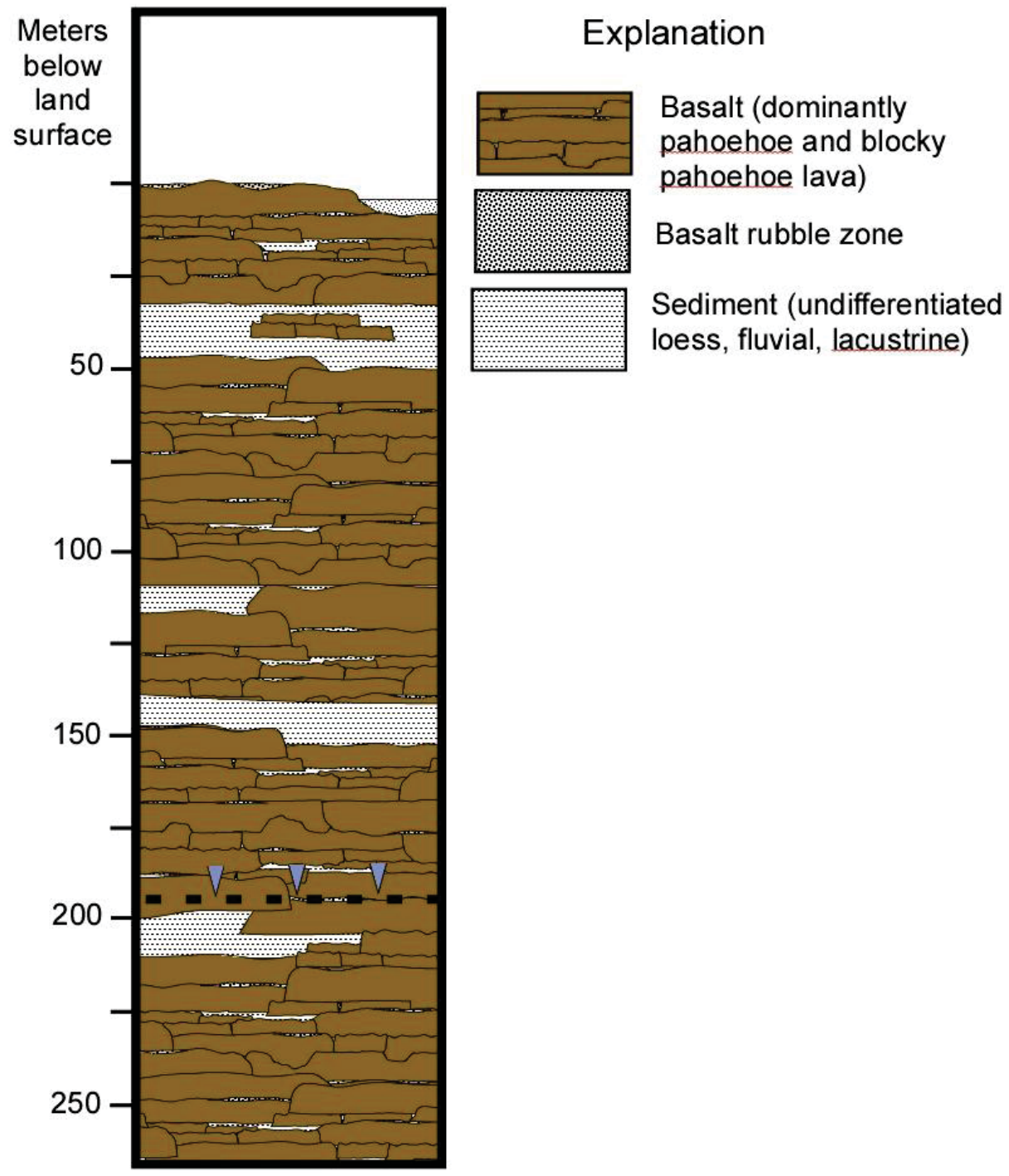

Figure 2. Schematic illustrating typical geologic stratigraphy at the INL, that includes horizontally extensive layers of fine sediments separating extensive thicknesses of fractured basalt.

Primary criteria for the proposed exhaust injection test, relative to gas transport are that

- backpressure at the injection point be limited to approximately 0.24 MPa (35 psi),

- gas velocities should be restricted to a Mach number of less than 1.0, in order to minimize backpressure and allow treatment of the flow problem using weakly compressible flow equations,

- induced pressure increase within the borehole should dissipate into the subsurface within a reasonable time after cessation of the injection, and 
- hydrogen injected will not be released to the atmosphere in such a way as to allow inadvertent combustion of the escaped gas.

In our examination of gas transport issues for this assessment, we consider primarily the first two of these criteria because the latter criteria are generally readily met if the forced flow can be accommodated and because the latter criteria depend on continuity of overlying lowpermeability layers discussed subsequently in the geology section of this report.

Backpressure develops in the subsurface exhaust injection scheme because of resistance in the well as well as resistance in the permeable porous medium targeted for injection. In the borehole, the resistance to flow depends on the radius of the hole and flow regime that develops under the specified injection rate, as the resistance to flow increases with increasing turbulence. In addition, at very high velocities, the backpressures that develop at locations of contrasting resistance result in changes in fluid density that also depends on pressure. Under the conditions specified for the Cooper and Decker test (2011), the combined volumetric gas flow of water and hydrogen is approximately $580 \mathrm{~m}^{3} \mathrm{~s}^{-1}$. The Mach number criterion thus requires that the radius of the borehole be approximately $0.61 \mathrm{~m}$ or greater. For any reasonable borehole dimensions, however, the flow regime will be turbulent, and significant backpressures can develop because of the resulting resistance. Assuming a 1.2-m radius borehole, the value used for similar calculations at the NTS, with an intrinsic friction length of $1 \mathrm{~mm}$, the pressure gradient that develops in the borehole is approximately $3 \mathrm{~Pa} \mathrm{~m}^{-1}$, indicating that if the radius is set to maintain flow in a regime where the gas may be treated as a nearly incompressible fluid, the backpressure associated with the borehole will be insignificant relative to that developed via flow into surrounding rock.

In the permeable porous medium, the resistance to flow is a function of the intrinsic permeability of the medium, the presence of other fluids within it, and - again - the flow regime that develops. In the Cooper and Decker (2011) simulations, the intrinsic permeability of the target formations was estimated as $10^{-11} \mathrm{~m}^{2}$. The transmissivity for the $490-\mathrm{m}$ thickness required to meet their design requirements was thus $4.9 \times 10^{-9} \mathrm{~m}^{3}$. At the INL, which is underlain by extensive basalt flows, permeability of the subsurface is primarily a result of the secondary porosity created by the fracture networks. Fractures are excellent conduits for fluid flow, and the permeability of a fracture varies as the square of the aperture. Thus, one small-aperture fracture 
can provide the same transmissivity as a much greater thickness of permeable porous medium. Figure 3, for example, illustrates the intrinsic transmissivity associated with a fracture of varying aperture, from which we can see that 10 horizontal continuous fractures of approximately $2 \mathrm{~mm}$ aperture could provide equivalent transmissivity to the entire 490-m thickness of permeable porous medium considered in the Cooper and Decker analysis for the NTS.

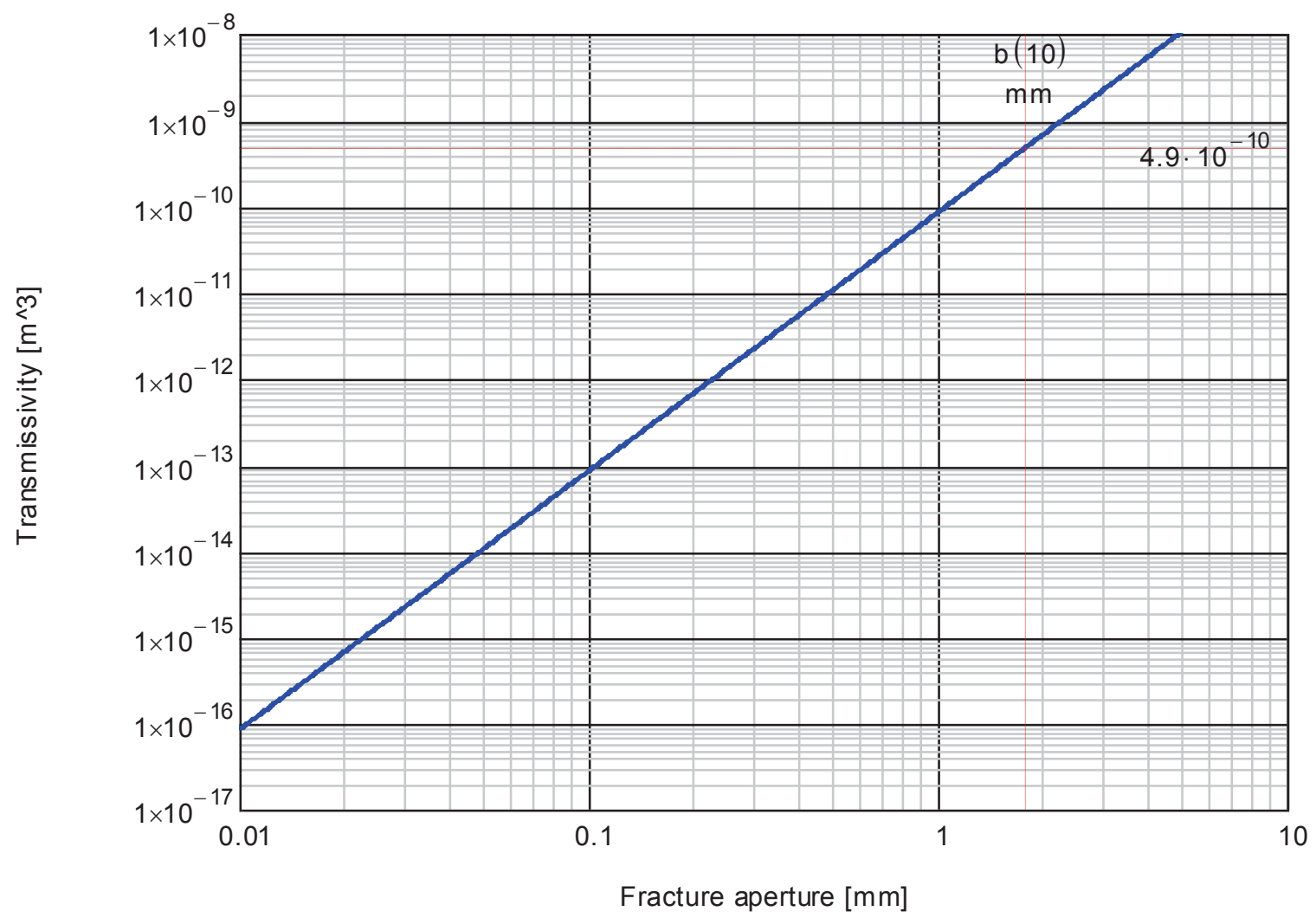

Figure 3. Transmissivity of a unit of rock in which fluid is transported through a single fracture of aperture specified on the abcissa. Red lines illustrate aperture for a set of $\mathbf{1 0}$ horizontal fractures with transmissivity matching that for which Cooper and Decker demonstrated that injection back pressure in a 1-m radius well would not exceed the design requirement of $0.24 \mathrm{MPa}$.

Permeability of a volume of fractured rock can thus be considerably higher than for an equivalent thickness of permeable porous medium and a variety of sources indicate that much of the basalts underlying the INL demonstrate this characteristic.

Much of the data describing permeability in the basalts underlying the INL stems from the numerous analyses aimed at understanding flow and transport in the prolific Snake River Plain aquifer, the major source of water for eastern Idaho. Ackerman (1991) indicates that 
permeability measurements from single-well aquifer tests at the INL Site range from less than $1 \times 10^{-12} \mathrm{~m}^{2}$ to approximately $1.7 \times 10^{-9} \mathrm{~m}^{2}$. Inverse model derived estimates of intrinsic permeability in the saturated zone at the INL range from $1 \times 10^{-12} \mathrm{~m}^{2}$ to $4 \times 10^{-9} \mathrm{~m}^{2}$, and while such measurements are, in part, constrained to match field data such as that described by Ackerman, the calculated value are effectively based on other field data, including abundant water level measurements throughout the Snake River Plain. Anderson, Kuntz, and Davis (1999), for example, reported that hydraulic conductivity in the vicinity of the INL Site ranged from less than 0.01 to more than $7,000 \mathrm{~m} / \mathrm{d}\left(1 \times 10^{-14} \mathrm{~m}^{2}\right.$ to $\left.7 \times 10^{-9} \mathrm{~m}^{2}\right)$, with most estimates exceeding 30 $\mathrm{m} / \mathrm{d}\left(3.5 \times 10^{-11} \mathrm{~m}^{2}\right)$. Permeabilities estimated from the transmissivity distribution used in groundwater models of the Snake River Plain aquifer of Robertson (1974) range from $5 \times 10^{-10} \mathrm{~m}^{2}$ to $2.1 \times 10^{-9} \mathrm{~m}^{2}$. Similarly, Garabedian's (1992) calibrated distribution of hydraulic conductivity within the area of the OU 10-08 model domain ranged from 1 to $335 \mathrm{~m} / \mathrm{d}\left(1 \times 10^{-12} \mathrm{~m}^{2}\right.$ to $3.35 \times 10^{-}$ $\left.{ }^{10} \mathrm{~m}^{2}\right)$.

The above described permeability estimates strongly indicate that the permeability of the fractured basalt underlying the INL is frequently high relative to the $10^{-11} \mathrm{~m}^{2}$ value used by Cooper and Decker for the NTS. If sufficient area with permeabilities toward the higher end of the reported range for the aquifer $\left(1 \times 10^{-10} \mathrm{~m}^{2}\right.$ to $\left.1 \times 10^{-9} \mathrm{~m}^{2}\right)$ can be found in the unsaturated zone, the required thickness could theoretically be one to two orders of magnitude less than required for the NTS. Several sources of data provide evidence that the vadose zone at the INL is also highly permeable. Well logs from numerous water wells provide direct evidence that numerous zones of highly fractured basalt extend across large areas of the site (reference?). Anecdotal evidence from air rotary drilling through the basalt also indicates that that the rock is highly permeable. Magnuson and Sondrup (2006), for example, indicate that before 1994, more than 40 wells were drilled without reverse-air circulation and in most of those wells "circulation (i.e., air recovery) was partially or totally lost below about $18 \mathrm{~m}$. These wells were typically drilled using air pressures of 125 to $250 \mathrm{psi}$ and injection rates of 0.35 to $0.52 \mathrm{~m}^{3} \mathrm{~s}^{-1}$. Finally, Mudra and Schmalz (1965) demonstrated high vadose zone permeability during gas injection testing completed at the INL as an appraisal of gaseous waste disposal potential.

Where it is desired to constrain the exhaust injection between two of the find-grained, lowpermeability, interbeds that extend across large areas of the site, the thickness of fractured basalt available is likely to be at least 150 feet. Assuming that thickness, and a permeability of $2 \times 10^{-9}$ 
$\mathrm{m}^{2}$ (considerably less than the highest reported permeabilities at the site), we can make a preliminary estimate of the backpressure that would develop via the Theis solution to the fluid flow problem to a well. The Theis solution gives the fluid pressure as a function of time and radial distance for a fully penetrating well in a transmissive medium of infinite radial extent. The solution assumes constant transmissivity and relatively small, and constant, compressibility, and the latter is a reasonable approximation for the gas flow if condensation and temperature effects are neglected, because the compressibility, and its pressure dependence, over the pressure difference prescribed by the design criterion, is minimal. The likely effects of heat transfer on the calculated backpressure will be discussed subsequently.

For the specified flow rate and well radius of $1.2 \mathrm{~m}$, a transmissivity of $9.1 \times 10^{-8} \mathrm{~m}^{3}$, an effective fluid viscosity of $1.9 \times 10^{-5} \mathrm{~Pa} \mathrm{~s}$, and a compressibility of $4.9 \times 10^{-6} \mathrm{~Pa}^{-1}$, the pressure vs radial distance profile that develops after 2 hours is shown in Figure 4. The absolute pressure at the exhaust injection point is $0.25 \mathrm{MPa}$, (gage pressure $=0.150 \mathrm{MPa}$ ), indicating that if the thermal effects associated with the injection (including condensation) do not have a negative feedback on the pressure gradient, the assumed conditions could meet the desired design criterion.

Cooling of the gas during transport through the subsurface will have two competing effects on the gas pressure in the injection well. First, cooling will directly reduce the pressure along the flow path according to the relationship described by the ideal gas law and the resultant water vapor condensation will reduce pressure because it effectively removes the steam portion of the gas flow. The former effect could effectively reduce the pressure by a factor of approximately 3 , while condensation would effectively remove approximately $10 \%$ of the volumetric flux. Second, condensation of water in the pores will reduce the cross-sectional area of the subsurface available for gas flow. Because this reduces fluid permeability, the condensation effect should also cause some increase in the backpressure that develops. As an indicator of the relative importance of these competing effects, we note that Cooper and Decker's (2011) simulations for such a test at the NTS suggested that the simulated conditions could meet the backpressure design criterion with relative saturations in the water condensation zone of up to $80 \%$, which would have likely reduced permeability to on the order of $1 \%$ of their intrinsic permeabilities. Given that permeabilities in the fractured rock at INL are generally much larger than in the NTS subsurface, the NTS simulations strongly suggest the desired maximum injection backpressure 
could also accommodate subsurface condensation effects at the INL. In addition, because the porosity of fractured basalt is considerably lower than the medium considered in the NTS calculations, the condensation zone is likely to penetrate much farther radially but cause similar changes in relative permeability. The effect of those changes should thus be smaller in a fractured system, because the pressure gradient decreases with radial distance from the injection point and the change in backpressure is proportional to the product of the pressure gradient and relative change in permeability.

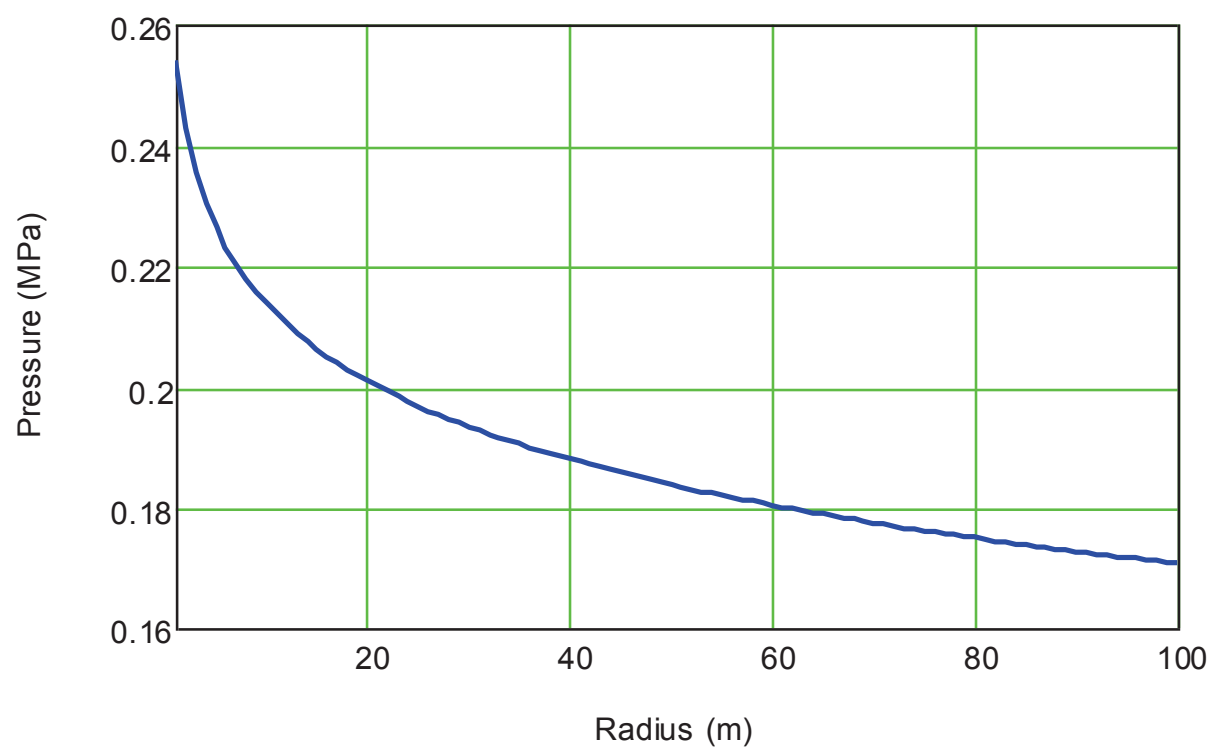

Figure 4. Pressure vs radial distance for the gas flow and well and flow conditions described in the text, calculated using the Theis solution for radial flow to a well in an infinite aquifer.

While permeability data from the Snake River Plain indicates that a zone of sufficiently high permeability for the exhaust injection test should be available at the INL, the porosity of the rock also plays an important role in defining site suitability. While a single fracture with relatively large aperture could theoretically provide the required transmissivity, the gas velocities in such a system would be extremely high, particularly at the borehole face, and the radial penetration would likely extend beyond distances over which confining units could be assumed to continuous. Higher velocities can also be disadvantageous by inducing turbulence, which increases the pressure gradient needed to drive flow through the system of fractures. If we consider a fracture network comprised of, for illustration, equally spaced, uniform, horizontal fractures of infinite extent that could accommodate the required gas flux under nearly 
incompressible laminar flow, the number of fractures required, and thus the secondary porosity, can be determined by constraining the Mach number to less than 0.3 . The required number of fractures is then $\sim 700$, and the implied aperture and spacing are, respectively, $1.0 \mathrm{~mm}$ and $6 \mathrm{~cm}$ and the implied porosity is 0.015 . For comparison, a recent large-scale modeling study of the Snake River Plain aquifer underlying the INL used a porosity of 0.062 , a value derived via calibration and that is consistent with values used in previous studies. Ackerman et al. (2006), for example, reported a range of porosity estimates from 0.05 to 0.27 derived from previous studies. Considering the volumetric gas flux of $580 \mathrm{~m}^{3} \mathrm{~s}^{-1}$ injected into such a system, and the $>40 \%$ volumetric reduction expected to occur during transport, the radial penetration distance at the end of a 2-hour test would be less than 600 meters in a uniform homogeneous system.

In summary, gas flow calculations suggest that the primary design criterion for the SAFE exhaust injection test could be met at the INL, in a zone of fractured rock approximately $150 \mathrm{ft}$ thick with laterally continuous permeability near the upper end of permeabilities measured at multiple locations in the Snake River Plain.

\section{INL Site Geological Assessment}

The goal of this portion of the report is to provide a high level assessment of the geologic conditions present at the INL that would support the SAFE concept for nuclear propulsion test facility. It provides a summary and analysis of the geologic architecture of the Idaho National laboratory (INL) relative to the needs of the test parameters provided by USRA and intended to provide a rational basis for assessment of possible site locations for field tests of SAFE Nuclear

Rocket technology at the Idaho National Laboratory. The identified regions would then be subject to more detailed examination as potential field test sites.

This assessment is based on a review of publicly accessible information regarding the geologic framework and hydrogeology of the shallow subsurface for the Idaho National Laboratory, emphasizing physical and chemical characteristics of the earth materials. Information sources include professional scientific publications, and relevant public-domain reports compiled from the DOE/INL (e.g., htttp:www.inl.gov/publications/), US Geological Survey, and State of Idaho. The assessment begins by listing geologically relevant site selection criteria that were established 
by project team members. It then summarizes key features of the geology and hydrogeology of INL. These features are then evaluated in the context of the site selection criteria. Parts of INL that satisfy those criteria are identified.

\section{Site Selection Criteria}

Based upon discussions within the project research group, the following specific site selection criteria have been established as geologically relevant NRT site requirements at INL:

- ${ }^{1}$ Vadose zone is required to have at least 450 feet depth below land surface (DBLS); i.e. aquifer is required to be at $>450$ feet below land surface

- Located $>\sim 2 \mathrm{~km}$ from site boundary or major roads/highways

- Located $>1 \mathrm{~km}$ from known contamination sites (e.g., RWMC, INTEC) and developed INL roads

- Avoid regions of active seismicity or geothermal activity

- Avoid regions of potential flooding

- Avoid regions that would provide structural pathways for vertical flow (e.g., faults, dikes, vents or volcanic rifts)

- Located $>1 \mathrm{~km}$ from known or potential sources of focused surface infiltration (e.g., Big Lost River; diversion ponds; playas; other regions of known rapid infiltration); anthropogenic wastewater recharge areas; and radiologically contaminated vadose zone or groundwater systems

- Permeable basalt interval thickness of $\geq \sim 300$ feet ('test interval')

- Aquitards ${ }^{2}$ (sedimentary interbeds) located both below and above fractured basalt test interval.

\section{Location}

The Idaho National Laboratory (INL) is located on the northern margin of the Eastern Snake River Plain (ESRP) in southeast Idaho (Figure 5). It is bordered to the north by mountains and

${ }^{1}$ Vadose zone is defined at the unsaturated zone that exists above a aquifer. In the case of the INL, the vadose zone is very thick - 200' to $700^{\prime}$ - and is composed of layered basalt and sedimentary interbeds.

${ }^{2}$ Aquitards are impermeable layers of sedimentary deposits that restrict the flow of water and gas. 
valleys of the northern Basin and Range province (e.g., Anders et al. 1989). Drainage is internal and derived mainly from the north via the Big Lost River, Little Lost River and Birch Creek, all of which converge into a broad sedimentary basin referred to as the Big Lost Trough (Geslin et al. 2002). Modern playa systems developed within this long-lived trough include the Big Lost River and Birch Creek Sinks. Underflow and infiltration have produced a robust open groundwater system referred to as the Eastern Snake River Plain aquifer (e.g., Garabedian 1992).

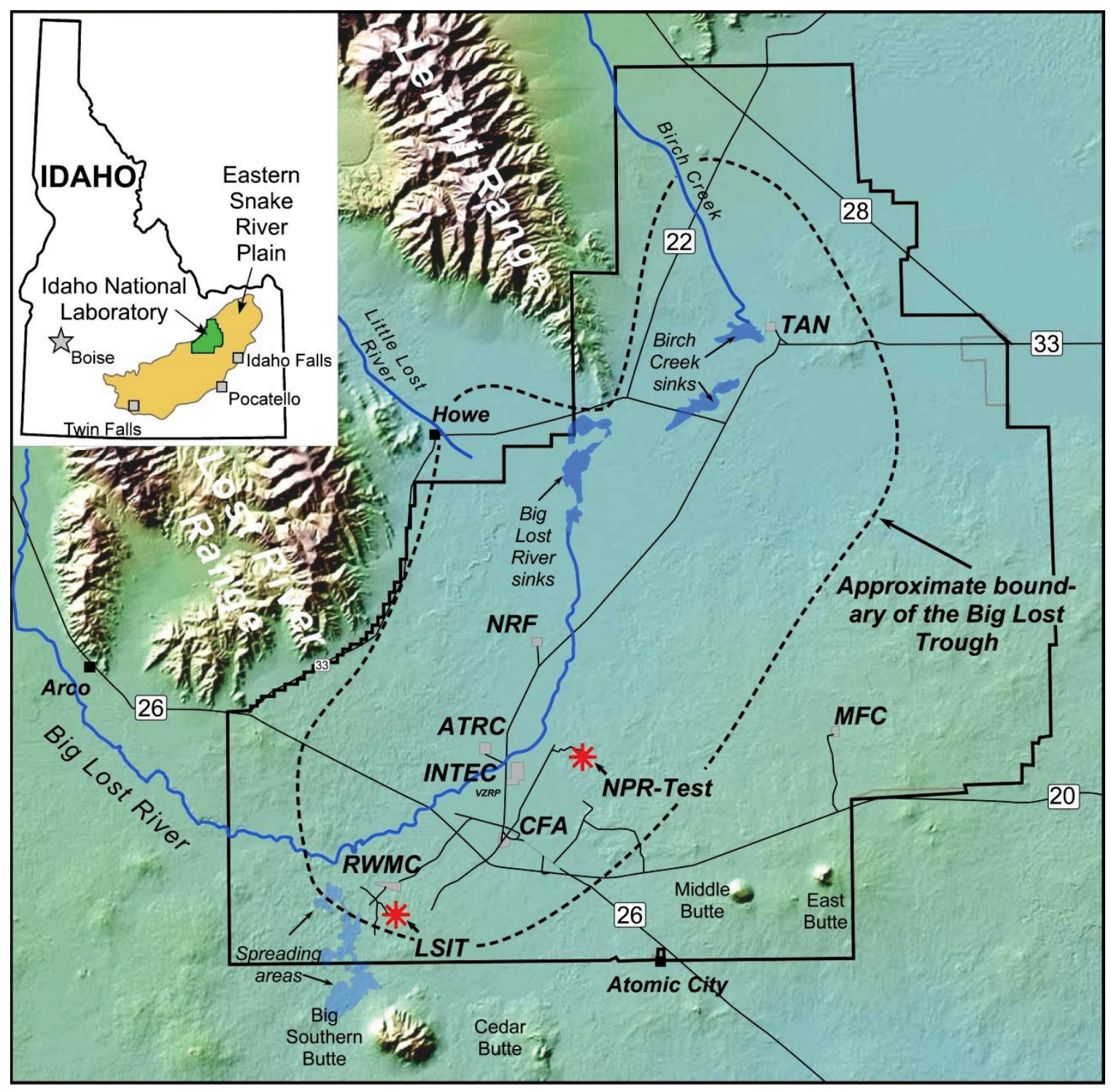

Figure 5. Location and digital elevation map of INL area illustrating geographic features, boundary of INL, and sites within INL.

A key site selection criterion for this report is that depth to aquifer must exceed 450 feet depth below land surface (DBLS), to ensure that there is an adequate zone for the test gas to diffuse. 
An additional benefit of selecting a location with at thick vadose zone is to provide sufficient protection to groundwater. The United States Geological Survey (USGS) maintains an active and robust monitoring program for the Eastern Snake River Plain and its aquifer (NWIS; Davis, 2010; Bartholomay et al. 2012). Figure 6 illustrates sites at which water levels are monitored periodically as part of their regulatory stewardship. The data have been hand contoured to illustrate spatial variations in depth to the water table below land surface (DBLS). DBLS increases generally from north at $\sim 250$ feet DBLS to $>700$ feet DBLS downgradient of the south margin of the INL. A bold line is drawn to illustrate parts of the INL having water tables depths less than (to the north) and more than (to the south) the 450 feet DBLS level. This line therefore represents a critical datum and constraint that will be referred to in subsequent illustrations and discussion.

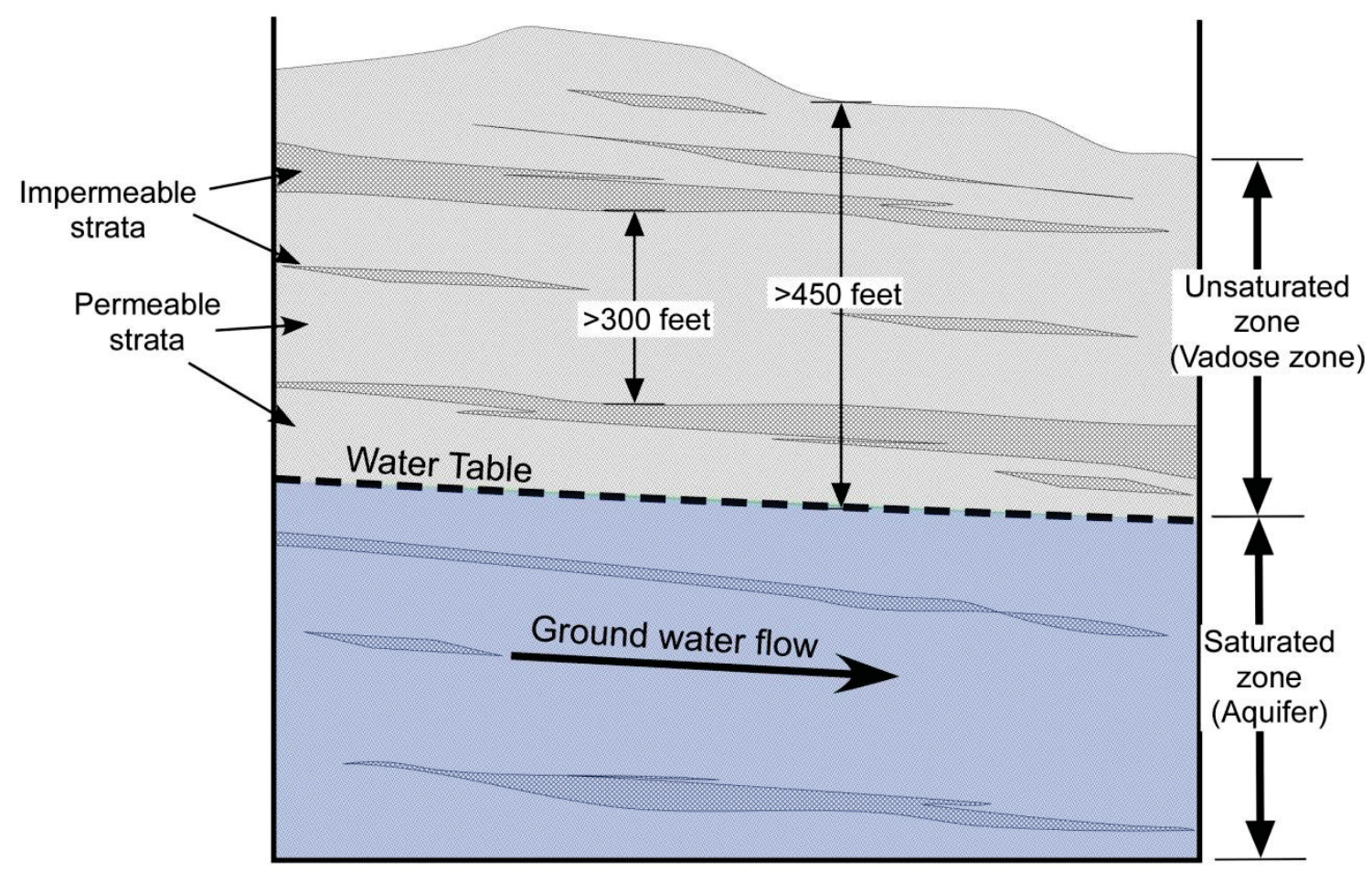

Figure 6. Illustration of key vadose zone geological site selection criteria.

\section{Regional Geology}

The INL is located on the northern margin of the Yellowstone-Snake River Plain volcanic track (YSRP) (Pierce and Morgan 1992), in the northern Basin and Range tectonic province (e.g., Anders et al. 1989). The volcanic track is the surface manifestation of an active continental hot 
spot and deep mantle plume that is currently located $\sim 100 \mathrm{mi}(160 \mathrm{~km})$ to the northeast of INL beneath Yellowstone National Park (Smith et al. 2009; Schmandt et al. 2012).

In the INL area, rhyolite volcanism and genetically related tectonic subsidence occurred between $\sim 10^{-4} \mathrm{Ma}$ (Morgan and McIntosh; Rodgers et al.). Over the last $4 \mathrm{~m}$.y. the post-hot spot track volcanism has been dominated by low intensity effusive basalt volcanism from 100's of widely scattered, overlapping, monogenetic shield volcanoes and northwest trending volcanic rift zones (Kuntz et al. 1992; Smith et al. 1996), and emplacement of scattered rhyolite cryptodomes and lava domes (e.g., McCurry et al. 2008). Basalt lavas incrementally accumulated to a thickness of up to $2 \mathrm{~km}$ thick in the center of the ESRP. A strong concentration of vents in the central ESRP produced a broad constructional topographic high that is referred to as the axial volcanic zone (AVZ) (Smith 2004; Hughes et al., 1999, 2002).

Concurrent with the basalt volcanism, southward-directed drainage into the ESRP from sources to the north produced layers of clastic sediment that are interlayered with basalt lavas (Bestland et al. 2002; Geslin et al. 2002). Construction of the Axial Volcanic Zone diverted the southward drainage into a broad basin referred to as the Big Lost Trough, that overlaps most of the INL (Figure 6). Smith (2004) summarizes many of the salient geologic features of the shallow subsurface at INL.

\section{Local Geologic Features}

The surficial geology north of the INL and vicinity is comprised of Paleozoic to Mesozoic age carbonate and clastic sedimentary rocks. Those rocks are tilted and faulted by range-bounding northwest trending, Miocene to Quaternary age normal faults (Rodgers et al. 2002). The faults die out to the south into the ESRP (Jackson et al. 2006). The Paleozoic and Mesozoic rocks are also tilted into the Snake River Plain due to crustal subsidence of ESRP over the last 10 m.y. (Rodgers et al. 2002).

At INL, the surface and near-surface geology is dominated by olivine tholeiite basalt lava flows (Figure 6). Surficial lavas are dominantly 200 to $600 \mathrm{ka}$. Ages decrease from northwest to southeast as a result of progressive subsidence of the ESRP (Rodgers et al. 2002). The basalts were erupted effusively from numerous overlapping shield volcanoes (Figure 7). Many of the vents are northwest trending, and also have cogenetic northwest trending fracture systems that

formed in response to shallow dike intrusions (e.g., Kuntz et al. 2002). Many of the vents also 
cluster into northwest trending 'rift zones' that may root at depths $\geq 1-3 \mathrm{~km}$ into deep crustal dike swarms (e.g., Holmes et al. 2008).

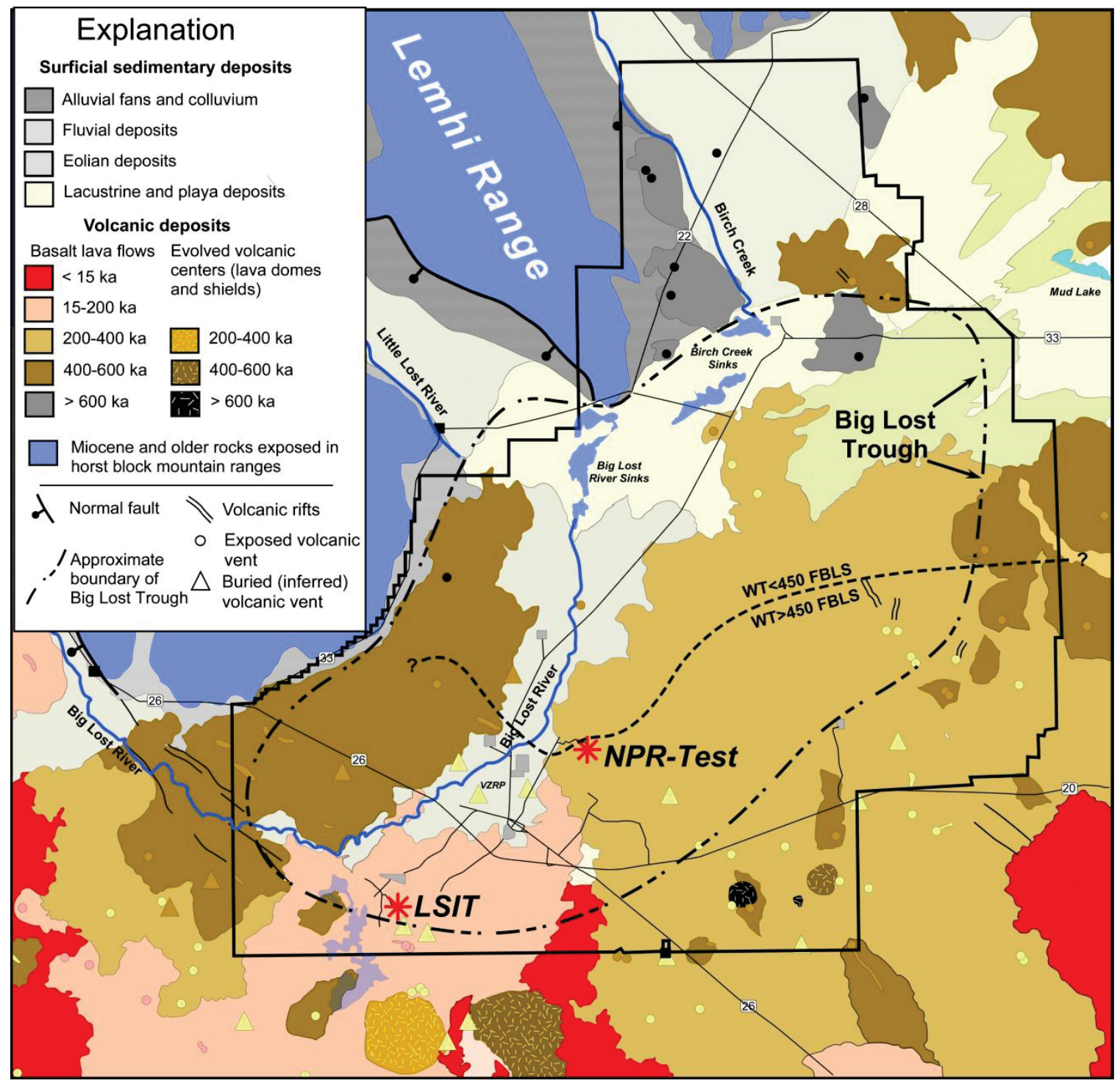

Figure 6. Surficial geology of INL and surroundings. Geology is simplified from maps by Kuntz et al. (1994; 2003). Locations of buried basalt vents are from Hughes et al. (2002) and Anderson and Liszewski (1998). 


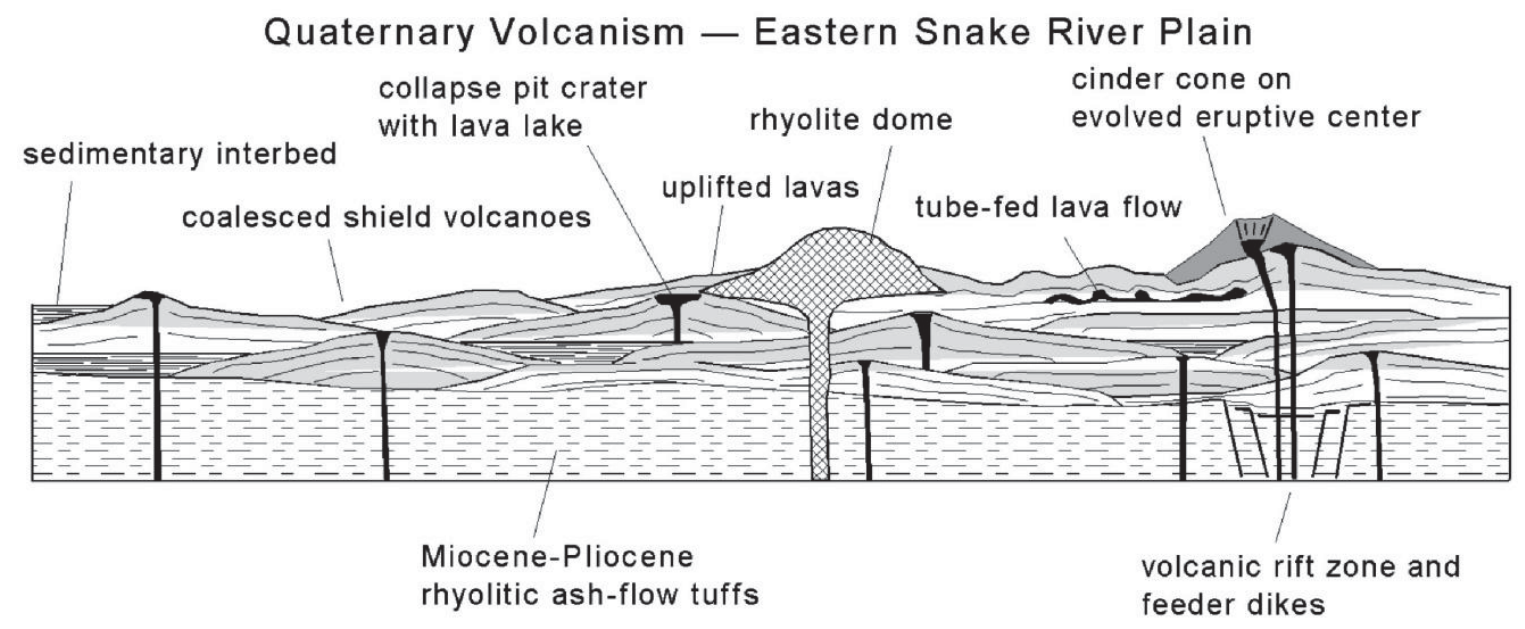

$(A)$

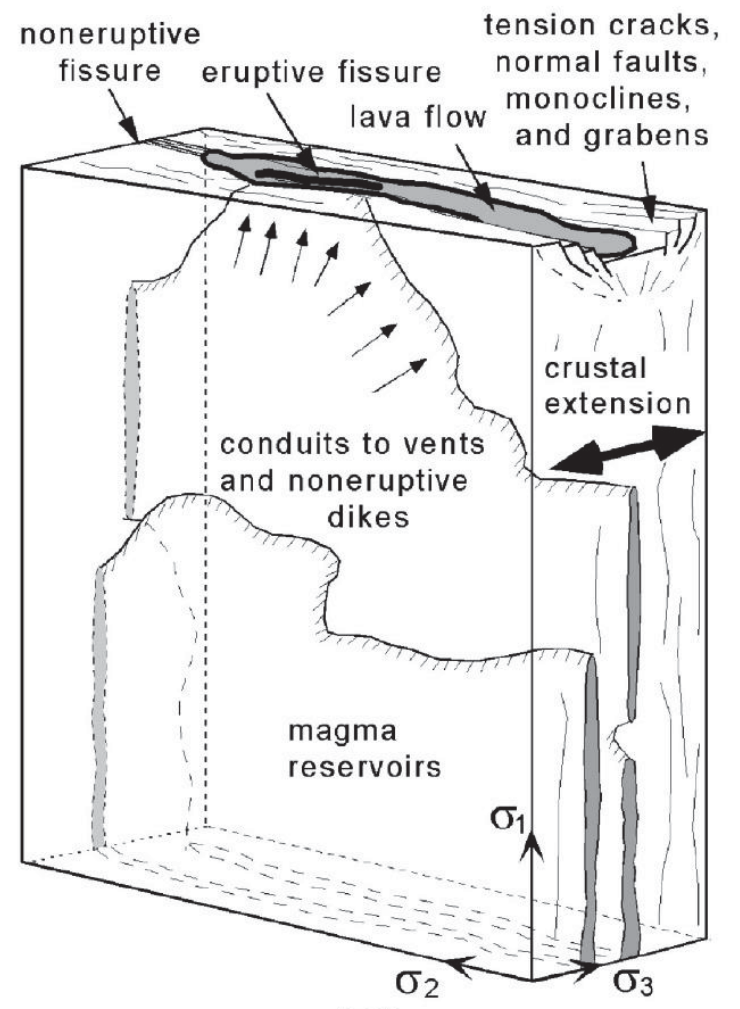

(B)

Figure 7. (A) Diagrammatic representation of interlayered volcanic and sedimentary deposits underlying the Eastern Snake River Plain (from Hughes et al. 2002). (B) Volcanic rocks were erupted within NW-trending volcanic rifts that in turn were produced by vertical dike swarms.

Southern parts of the INL are underlain by an unusually high concentration of basaltic vents, and also intermediate to rhyolitic lava domes and cryptodomes (McCurry et al. 2008). Basalt lavas as young $12 \mathrm{ka}$ (Cerro Grande lava) to $5.1 \mathrm{ka}$ (Hell's Half acre) were erupted from vents along the AFZ just south of the INL. Basalt lavas at INL are widely overlain by a thin $(<$ few meters), 
discontinuous veneer of loess (REFs), most of which is $<14 \mathrm{ka}$. They are also overlain and interlayered with clastic fluvial and lacustrine sediments that collected over the last few million years into the Big Lost Trough. Those sediments are thickest along the channel of the Big Lost River and in central and northern parts of INL (Figure 6).

\section{Geologic Hazards}

For more than six decades the INL has been home to a large number of nuclear research projects including the construction of more than 40 reactors. As a consequence, a significant amount of effort has been directed towards characterizing the geologic hazards at the INL, which are primarily flooding, seismicity and volcanism. The characterization of these hazards is discussed in detail in the following references Ostenaa et al. 2002; Northwind (2011), p. 66, Anders et al. (1989); Smith et al. (2009) Jackson et al. (1993). The summary of these assessments is that in spite of the INL's proximity to active geologic faults, the ESRP has been remarkably free of seismic activity for thousands of years.

\section{Borehole studies}

Over the last six decades numerous boreholes have been constructed to monitor aquifer conditions and also to define the three-dimensional architecture of the vadose and active groundwater systems at INL. These data have recently been integrated into comprehensive models for the southern half of INL (Champion et al. 2011; Hodges et al. 2012; Twining et al. 2008). Additional borehole characterization is available for specific sites in the northern half of INL (e.g., at 2-2A, and near TAN, e.g., Bestland et al. 2002; Anderson and Bowers 1995).

Cross-section models depicting the large-scale subsurface architecture at INL, based on surficial geology and borehole data (Figure 7) are shown in Figure 8. Subsurface correlations of basaltic lava flows and flow groups are robust from land surface to between 200 and 400 meters DBLS. They are based upon multiple correlation criteria including lava flow radiometric ages, paleomagnetic inclinations and polarity, bulk rock chemistry and mineralogy, electric log data (e.g., natural gamma), and lava flow facies analysis. Additional criteria exist for specific boreholes, including bulk rock isotopic compositions and phenocryst compositions (e.g., Hughes et al. 2002). Champion et al. (2011) work is augmented by work along the southern margin of INL by numerous other studies (e.g., Hodges et al. 2012; Twining et al. 2008). Collectively these studies yield a clear understanding of the large-scale architecture for much of the southern half of 
INL, in particular those areas that satisfy minimum vadose thickness requirements (i.e. $\geq 450$ feet).

Champion et al. (2011) focused on correlations of lava flow groups, i.e. the collected sequence of cogenetic lavas produced during the life cycle of single monogenetic volcanoes. Sediment interbeds make up $<10 \%$ of the subsurface architecture and form impermeable barriers to vertical fluid flow. Flow groups vary up to 100 meters thick near centers of the paleo-shield volcanoes forming thick sections of layered basalt that make ideal targets for the SAFE test.

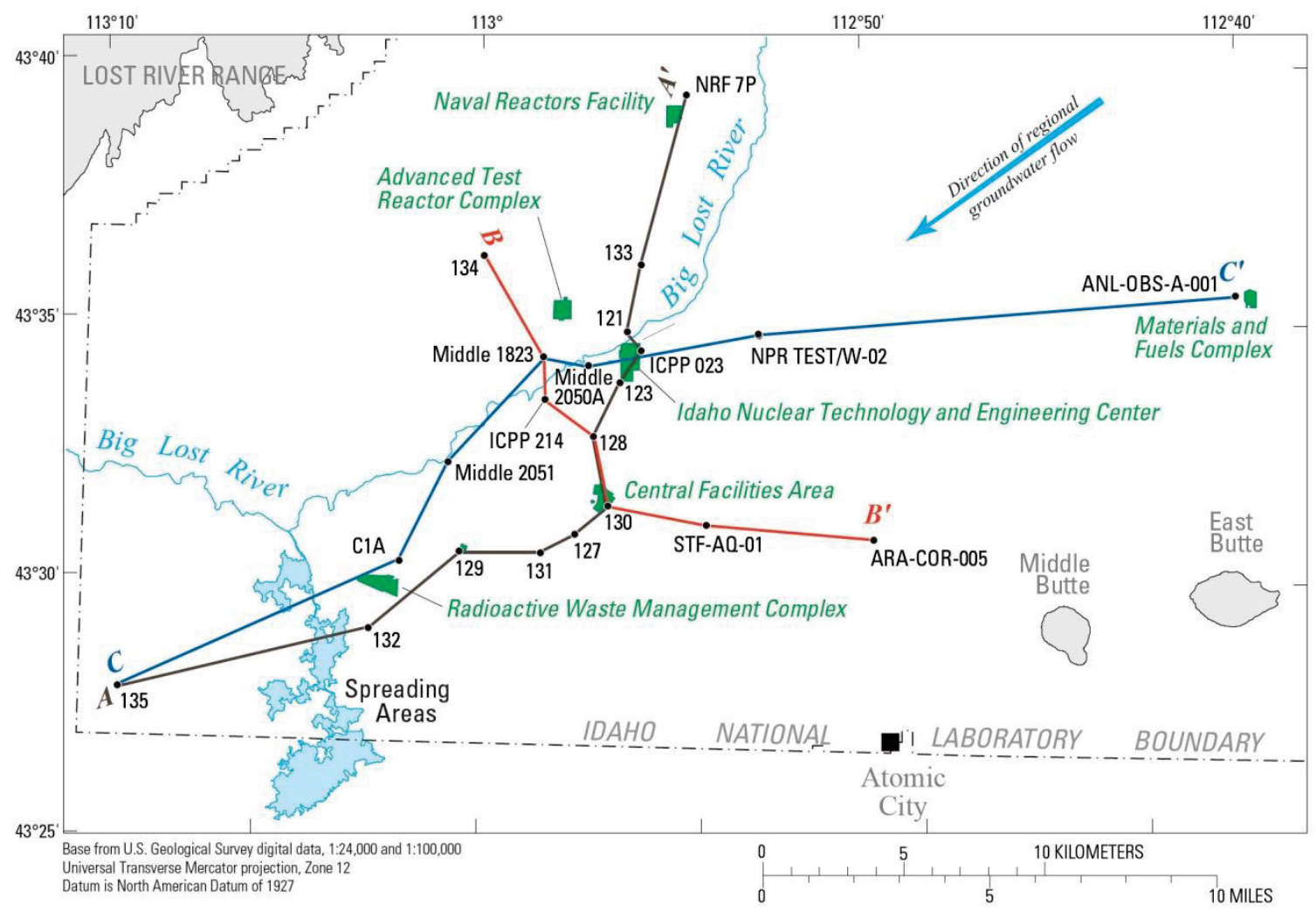

Figure 7. Location map illustrating locations of surface- and borehole-constrained geologic cross-sections of INL. 


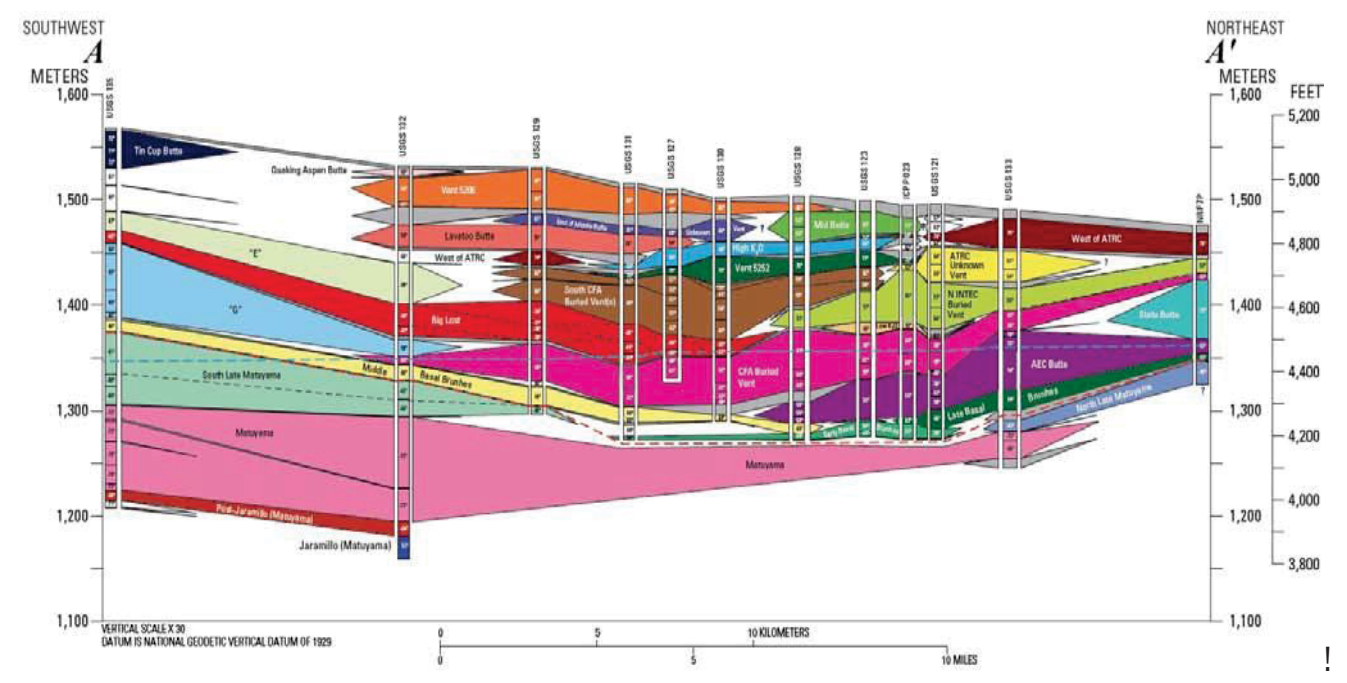

Figure 8. Cross-sections of vadose zone and upper parts of the Eastern Snake River Plain across southern parts of the INL (from Champion et al. 2011).

\section{Subsurface lithology}

\section{Basalt lavas}

The shallow subsurface architecture for the southern half of INL is dominated by inflationary pahoehoe lava flows (Welhan et al. 2002). A model for the hydrogeologically salient physical features of the lavas is illustrated in Figure 9. Permeability is highly variable in vertical section of flow lobes, and is dominated by fractures and interflow rubbles zones, some of which have extremely high values of hydraulic conductivity (e.g., Ackerman 1991, p. 30; Bartholomay et al. 2000 , p. 15). Strong variation is also observed in longitudinal (proximal to distal) and crosssectional (lobate) views of the lavas. Welhan et al. (2002a, b) summarize key types and hydrogeological scaling properties of the basalt lavas. The net result of the basalt depositional architecture, as shown in Figure 9, is a highly heterogeneous hydrologic system where horizontal permiability is extremely high relative to vertical permeability. 


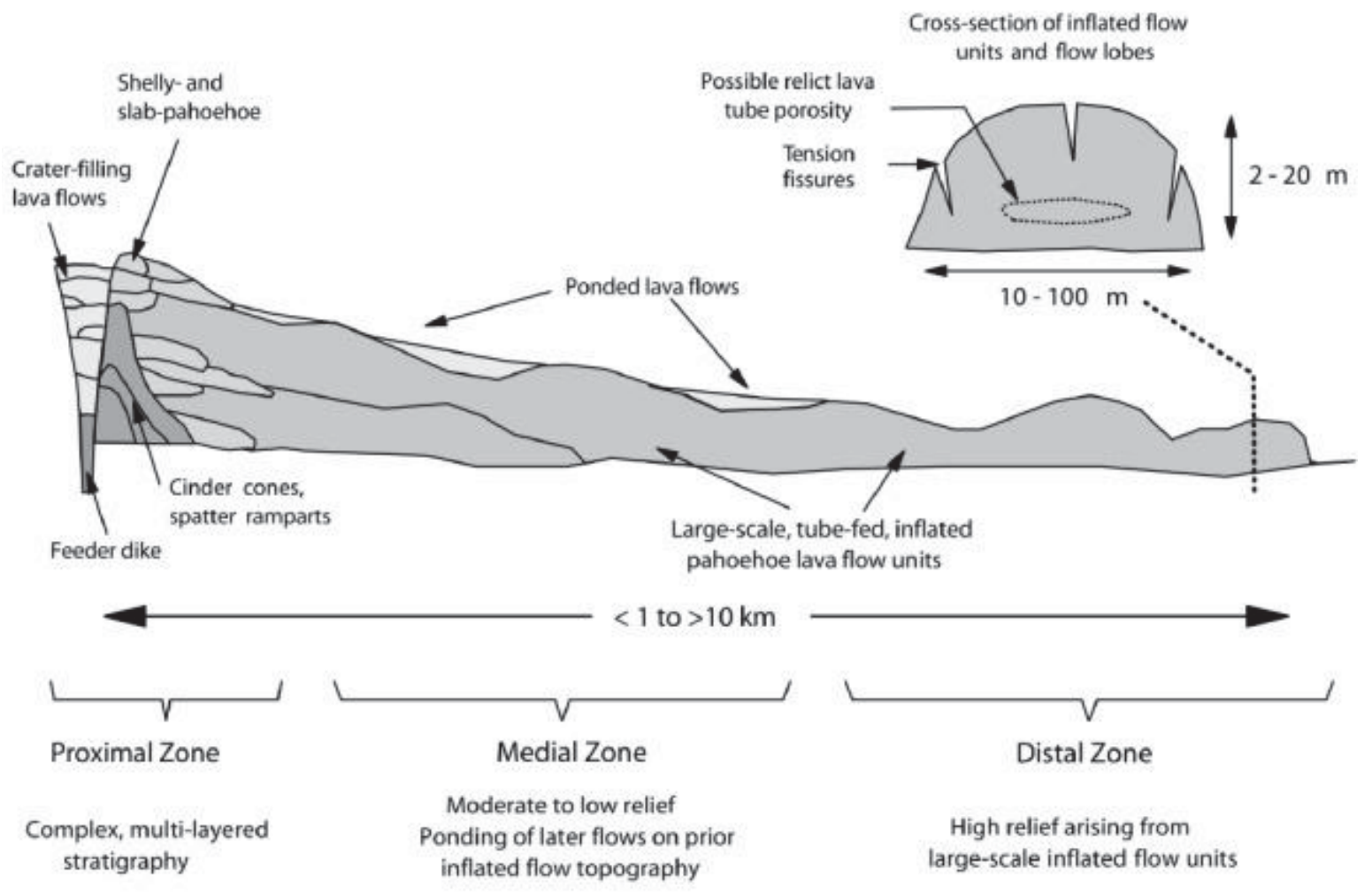

Figure 9. A: Vent to toe cross--section illustrating key hydrogeological features of basalts lava flows (from Welhan et al. 2002).

\section{Sedimentary interbreeds}

The distribution of permeability in the SRPA is spatially and vertically variable and is strongly impacted by the distribution of sedimentary interbeds deposited on the basalt by wind and water. The distribution of sedimentary interbeds within the basalt flows is controlled periods of volcanic quiescence accompanied by fluvial or lucustrine sedimentation. Sedimentary interbeds generally make up less than $10 \%$ of the volume of the vadose zone in the southern half of INL. Although volumetrically small the sediment interbeds are composed of fine-grained sediment layers (clays and silt) that act as key aquitards (e.g., Winfield 2005). Fine-grained sediments also infiltrate into underlying basalt lavas reducing their porosity and the vertical permeability of the system.

Sediment interbeds vary from a thin mantling of the basalt to over 100 feet in thickness. Lateral (horizontal) extent of the interbeds is often difficult to constrain from borehole data, but appears to vary from 10's meters up to a few kilometers (Stroup et al. 2008; Welhan et al. 2006). 


\section{Application of site selection criteria:}

The following discussion is a step-wise application of site selection criteria to the INL.

\section{Summary of site selection criteria}

1) Vadose zone thickness $\geq 450$ feet

2) Located $>\sim 2 \mathrm{~km}$ from site boundary or major roads/highways

3) Located $>1 \mathrm{~km}$ from know contamination sites (e.g., RWMC, INTEC) and major roads;

4) Avoid regions of active seismicity or geothermal activity

5) Avoid regions of potential flooding

6) Avoid regions that would provide structural pathways for vertical flow (e.g., faults, dikes, vents or volcanic rifts)

7) Located $>1 \mathrm{~km}$ from known or potential sources of surface infiltration (e.g., BLR; diversion ponds; playas; other regions of known rapid infiltration); anthropogenic wastewater recharge areas; and radiologically contaminated vadose zone or groundwater systems

8) Permeable basalt interval thickness of $\geq \sim 300$ feet ('test interval')

9) Aquitards located both below and above basalt test interval

\section{Criteria 1-3:}

Figure 10 illustrates parts of INL, which satisfy criteria 1-3. Parts of the INL satisfying these criteria are shaded green. Depth to water table is contoured specifically for 2010 to present.

Criterion 4: Avoid regions having active seismicity or geothermal activity.

There is no known geothermal activity at INL. Seismicity is infrequent and of low intensity, and is therefore not considered to be a site exclusion factor at INL.

Criterion 5: Avoid regions of potential flooding.

Flood hazards are restricted to regions along the Big Lost River, the Big Lost River diversion area, and in the sinks areas of northern INL. These areas have already been excluded from site consideration because of failure to pass previous site selection criteria.

Criterion 6: Avoid regions that would provide preferred pathways for vertical fluid flow (e.g., faults, dikes, vents or volcanic rifts). 
No significant tectonic faulting occurs on INL. Tectonic faults are therefore not considered to be a site exclusion factor at INL. Other geologic features, such as volcanic vents, dikes or rifts, are concentrated in AVA and labeled rift zones (Figure 11). The H-EB (Howe-East Butte) rift is distinguished from the other rift zones (ARZ, LR-HHA and CB-KB) in lacking evidence for riftrelated activity south of the Lost River sinks and north of AVZ. That part of the rift is therefore retained for possible site selection. Site selection criterion six excludes easternmost parts of INL from consideration, as shown in Figure 11.

Criterion 7: Located $>1 \mathrm{~km}$ from known or potential sources of surface infiltration (e.g., BLR; diversion ponds; playas; other regions of known rapid infiltration); anthropogenic wastewater recharge areas; and radiologically contaminated vadose zone or groundwater systems.

Following from Busenberg et al. (2001), Figure 12 illustrates regions at INL that are distinguished by rapid recharge - mainly the sinks, AVZ and Big Lost River diversion and spreading area (yellow), regions affected by anthropogenic recharge to the aquifer (purple). Regions of INL that have tritium groundwater contamination $>500$ picocuries/liter (an assumed upper limit for site selection) are from Davis et al. (2010), and are shown in pink.

\section{Criteria 1-3 summary:}

Parts of INL passing site selection criteria 1-7 are illustrated in Figure 13. Areas labeled A1 and A2 are relatively well characterized by borehole data, and are preferred for further site assessment over less well-characterized parts of INL labeled B1 and B2.

\section{Criteria 8 and 9:}

Parts of potential site selection areas A1 (at LSIT) and A2 (borehole NPR-Test) have been well characterized for their subsurface stratigraphy. Figure 14 illustrates the subsurface stratigraphy in test area A1 near LSIT (Champion et al. 2011, borehole USGS 132). Water table depth is 180 meters (590 feet). Basalt lavas dominate borehole 132. Sedimentary interbeds occur at approximately $10 \mathrm{~m}$ (33 feet), 45 (150 feet) and 150 meters (490 feet) DBLS. Interbeds therefore bracket the minimum site selection criteria of $\geq 350$ feet. Lateral extent of the interbed sediments is not well constrained. Figure 15 illustrates a conceptual model of interbeds at SDA (RWMC), 2-3 km north of LSIT. It is possible that SDA interbeds number BC and FG may correlate with 
interbeds at similar depth at LSIT (borehole USGS132), suggesting that lateral continuity of those beds occurs at least at the scale of kilometers.

Figure 16 illustrates stratigraphy for borehole NPR-Test, located in test area A2. Water table depth at that site is 474 feet, exceeding minimum depth requirement of 450 feet. Basalt lavas dominate borehole stratigraphy. Fine Sediment interbeds occur at depths of $30 \mathrm{~m}$ (100 feet), 76 $\mathrm{m}$ (250 feet) and $125 \mathrm{~m}$ (410 feet) DBLS. Borehole NPR-Test therefore also meets site selection criteria. At NPR-Test, as in the case of LSIT, lateral continuity of the sediment interbeds is poorly constrained. Correlations of basalt lavas between NPR-Test and borehole USGS 123, located near INTEC, and about $5 \mathrm{~km}$ west of NPR-Test, suggest that NPR-Test interbeds at 100 and 250 feet DBLS may also be correlated between the two boreholes. However the 410-foot interbed at NPR-Test does not appear to extend as far as the USGS 123 borehole.

\section{Summary of application of site selection criteria:}

The geologic architecture of the Eastern Snake River Plain is well suited for the SAFE concept test, due to the regions layer cake geologic structure, and thick unsaturated zone. The geologic conditions found within the ESRP due to a very high horizontal to vertical permeability. This would allow for rapid dispersal of propulsion gas while limiting the vertical transport to the surface or to the deeper groundwater system. Geologically based site selection criteria have been used to identify areas of the INL for consideration for testing of the SAFE concept. Application of these criteria indicates that three regions within the INL should be considered as potential test sites. Parts of two areas (labeled B1 and B2 in Figure 14) are too poorly characterized by existing subsurface data for evaluation of all site selection criteria. These two areas are not considered, as they would require a significant amount of effort to characterize. Parts of two other areas (A1 and A2) satisfy all the site selection criteria and should be considered for a more detailed assessment. This report recommends that subsequent consideration of test sites focus on regions located at or near LSIT and NPR-Test. 


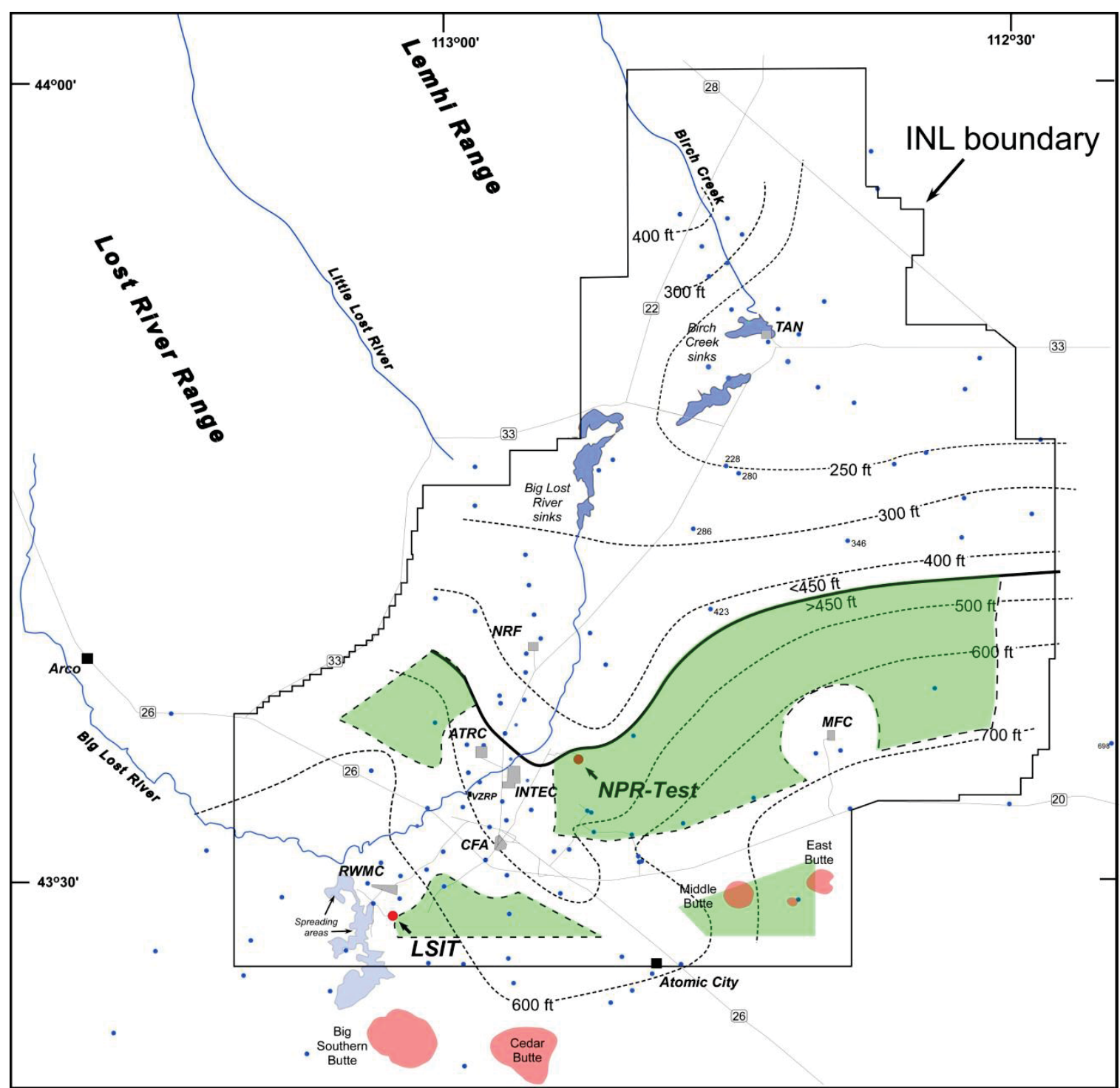

Figure 10. Map illustrating parts of INL that pass site selection criteria 1 through 3. 


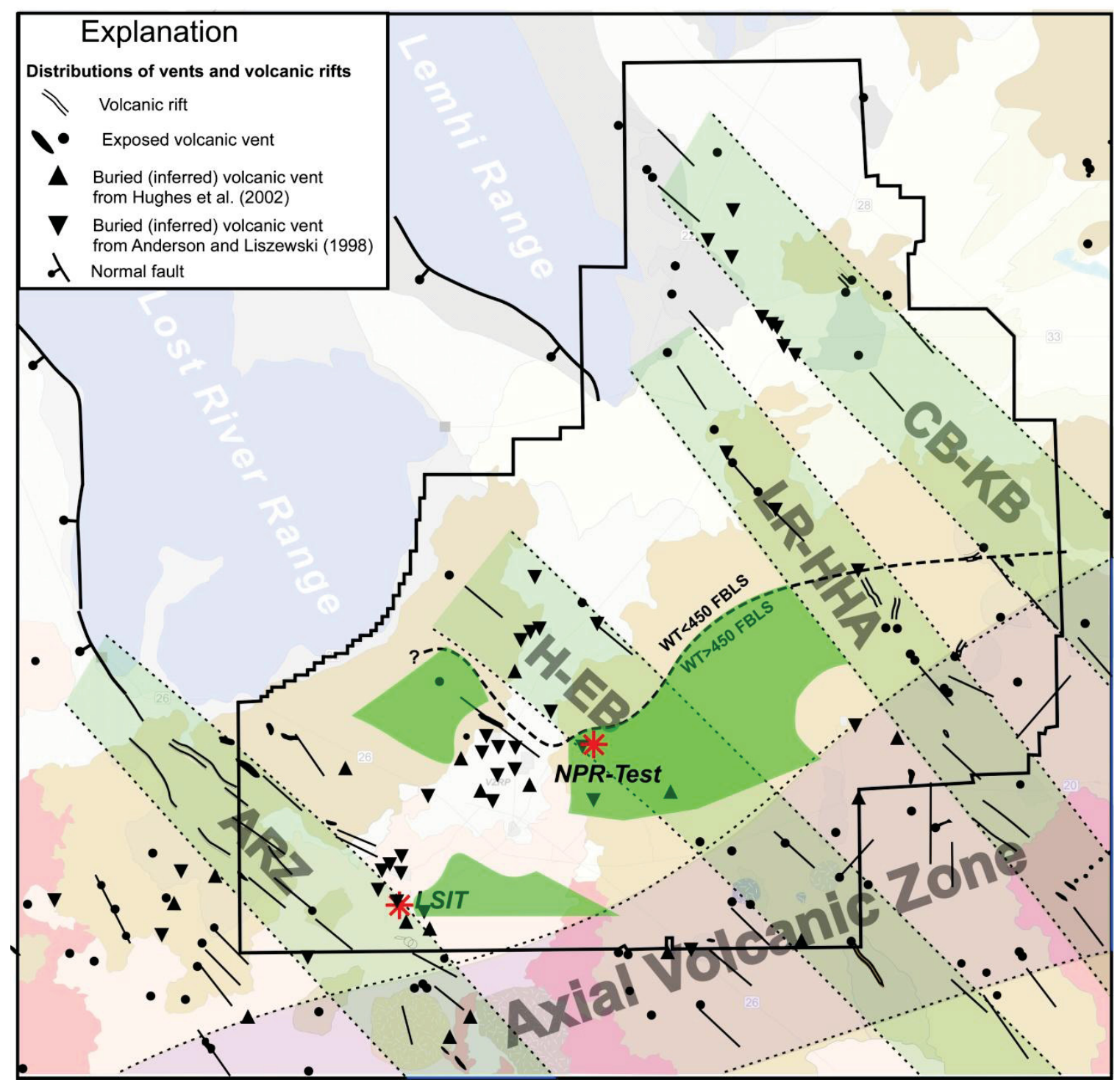

Figure 11. Map illustrating parts of INL that pass site selection criteria 1 through 6. 


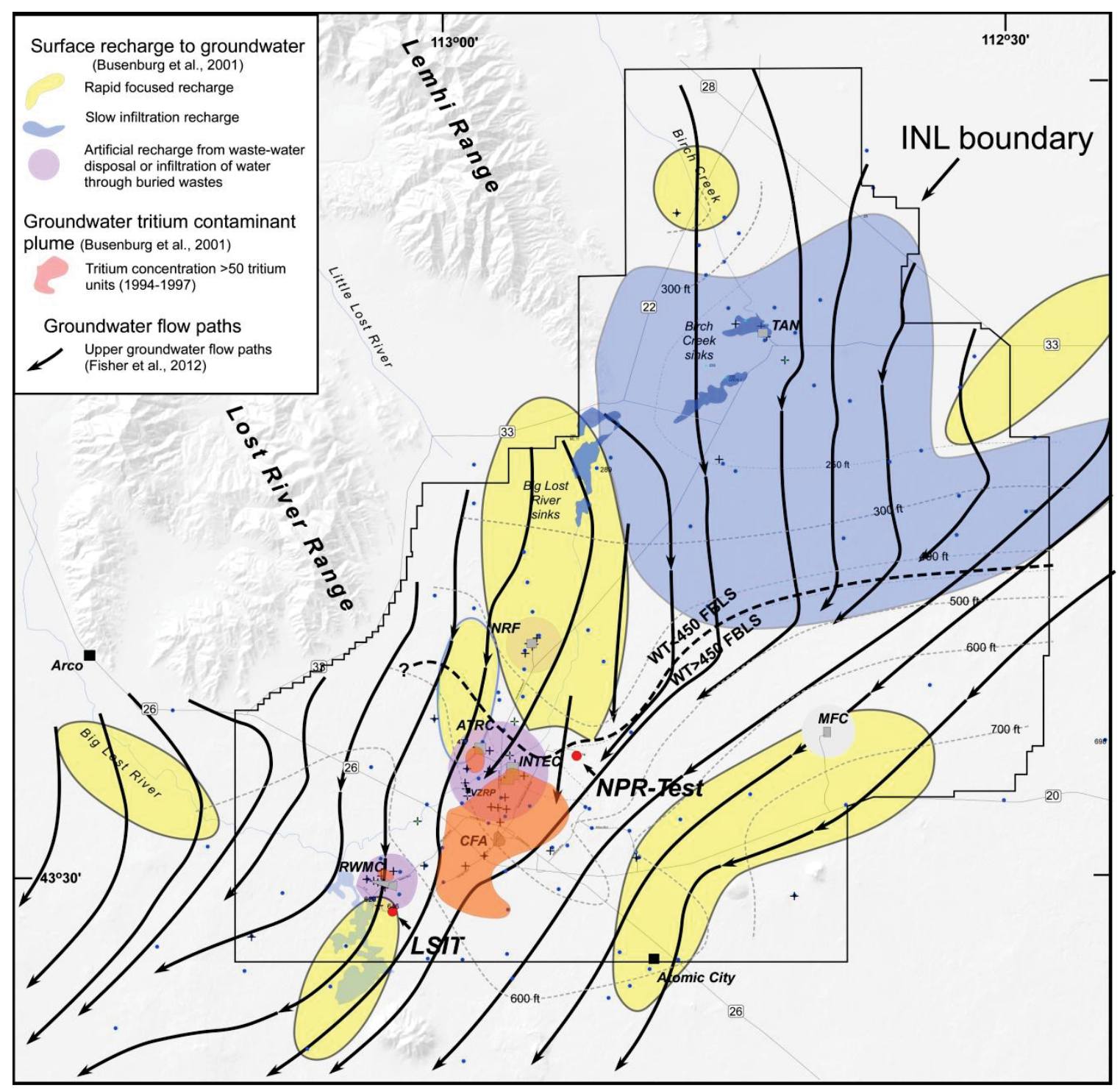

Figure 12. Following Busenberg et al. (2001) this figure illustrates regions at INL that are distinguished by rapid recharge - mainly the sinks, AVZ and Big Lost River diversion and spreading areas (yellow); and regions affected by anthropogenic recharge to the aquifer (purple). The figure also illustrates flow paths for ground water in the upper parts of the ESRP aquifer (after Fisher et al. 2012). 


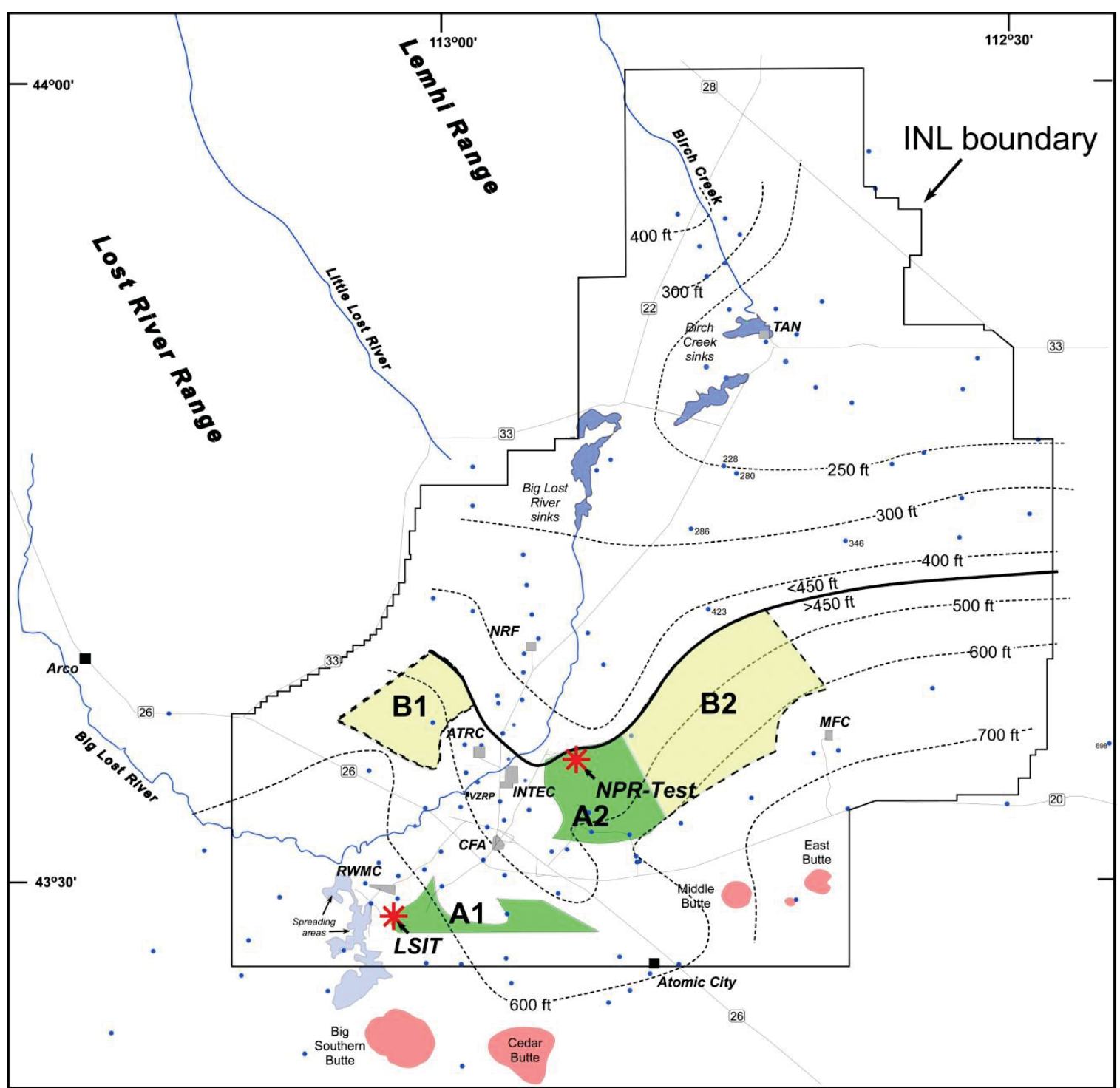

Figure 13. Map illustrating parts of INL that pass site selection criteria 1 through 7. 


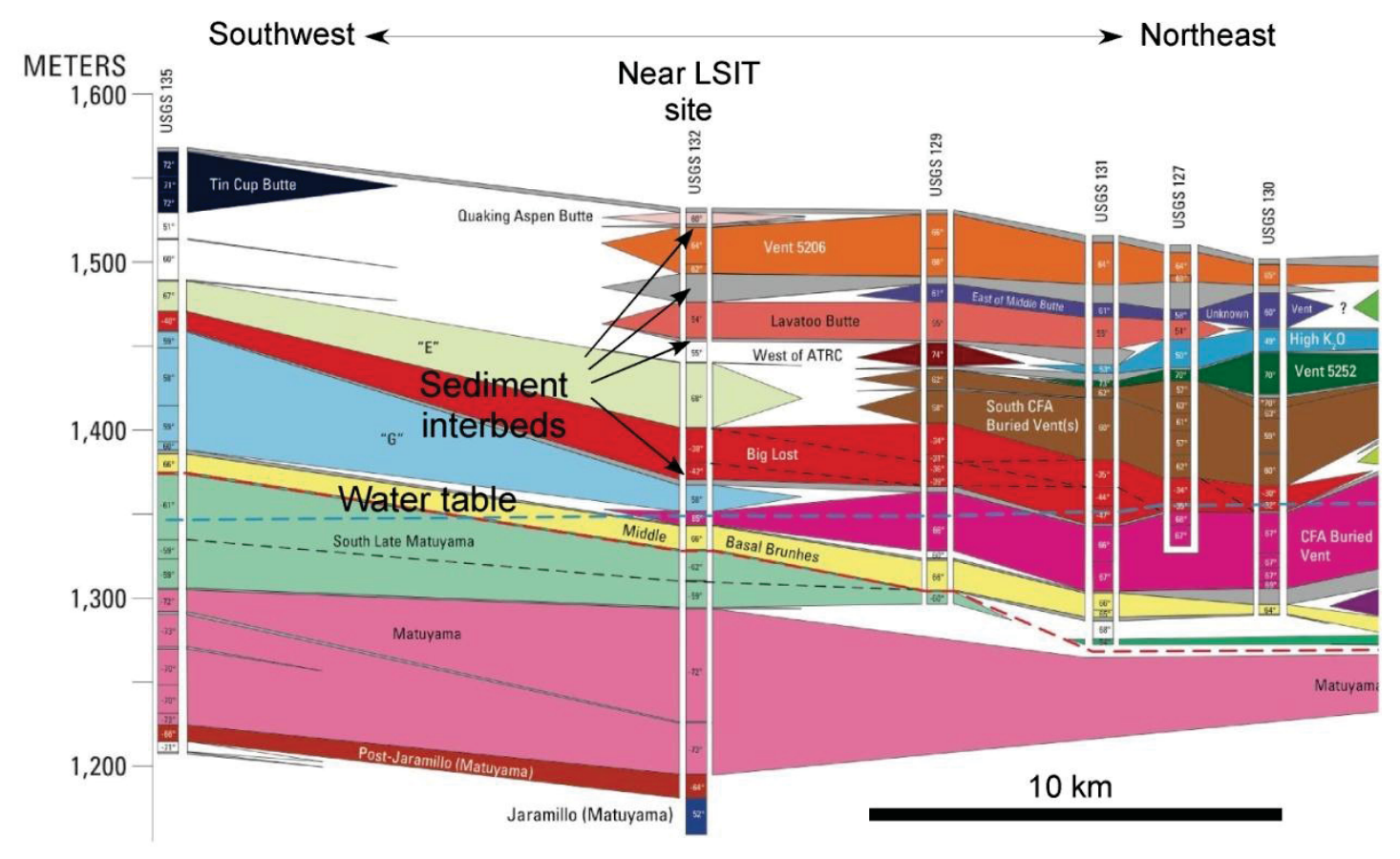

Figure 14. Summary and correlation fence diagram for subsurface stratigraphy near LSIT (from Champion et al., 2011).

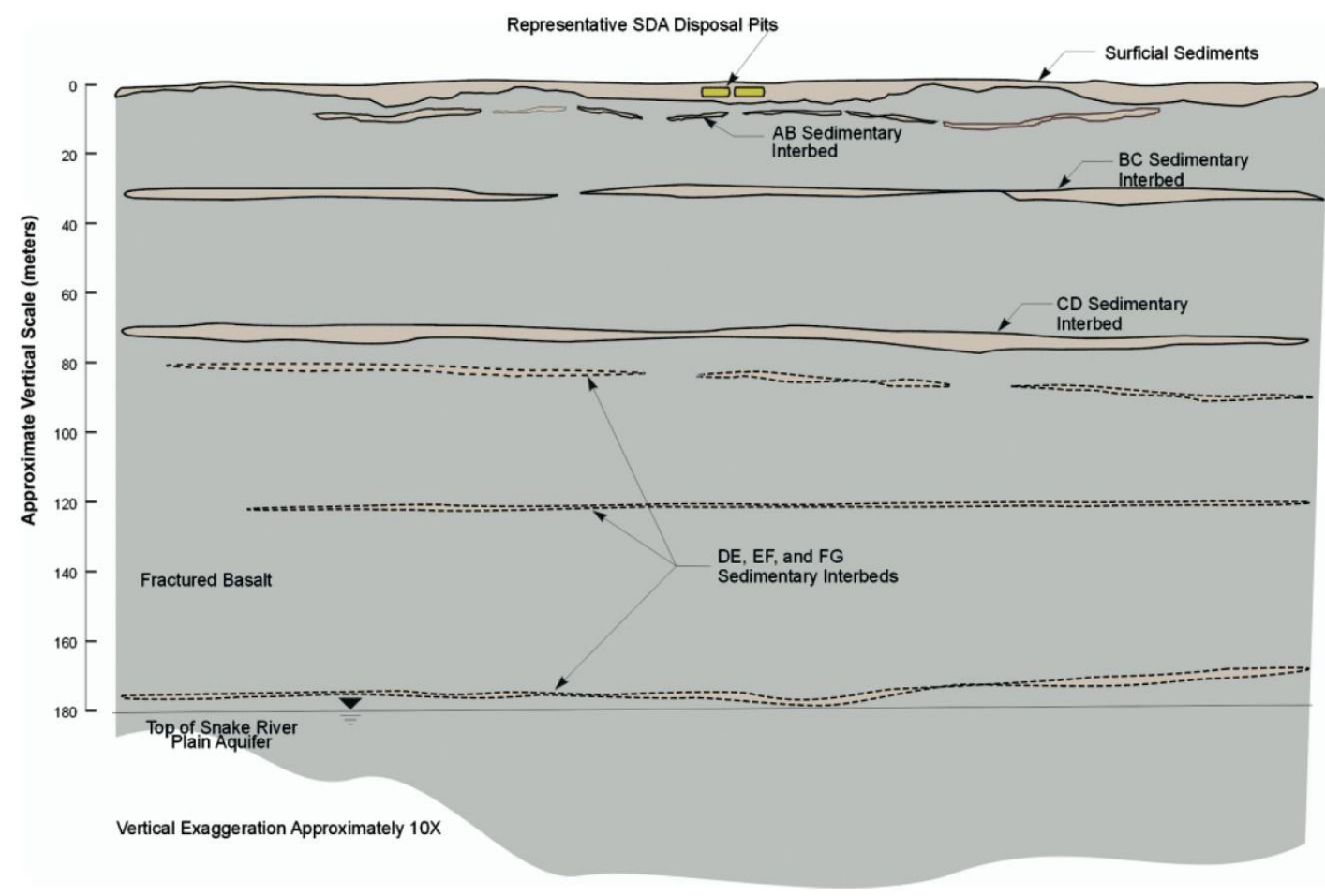

Figure 15. Complex interbedding of basalt lavas and sediments at the Subsurface Disposal Area (RWMC area) (from Magnuson, 2004). 


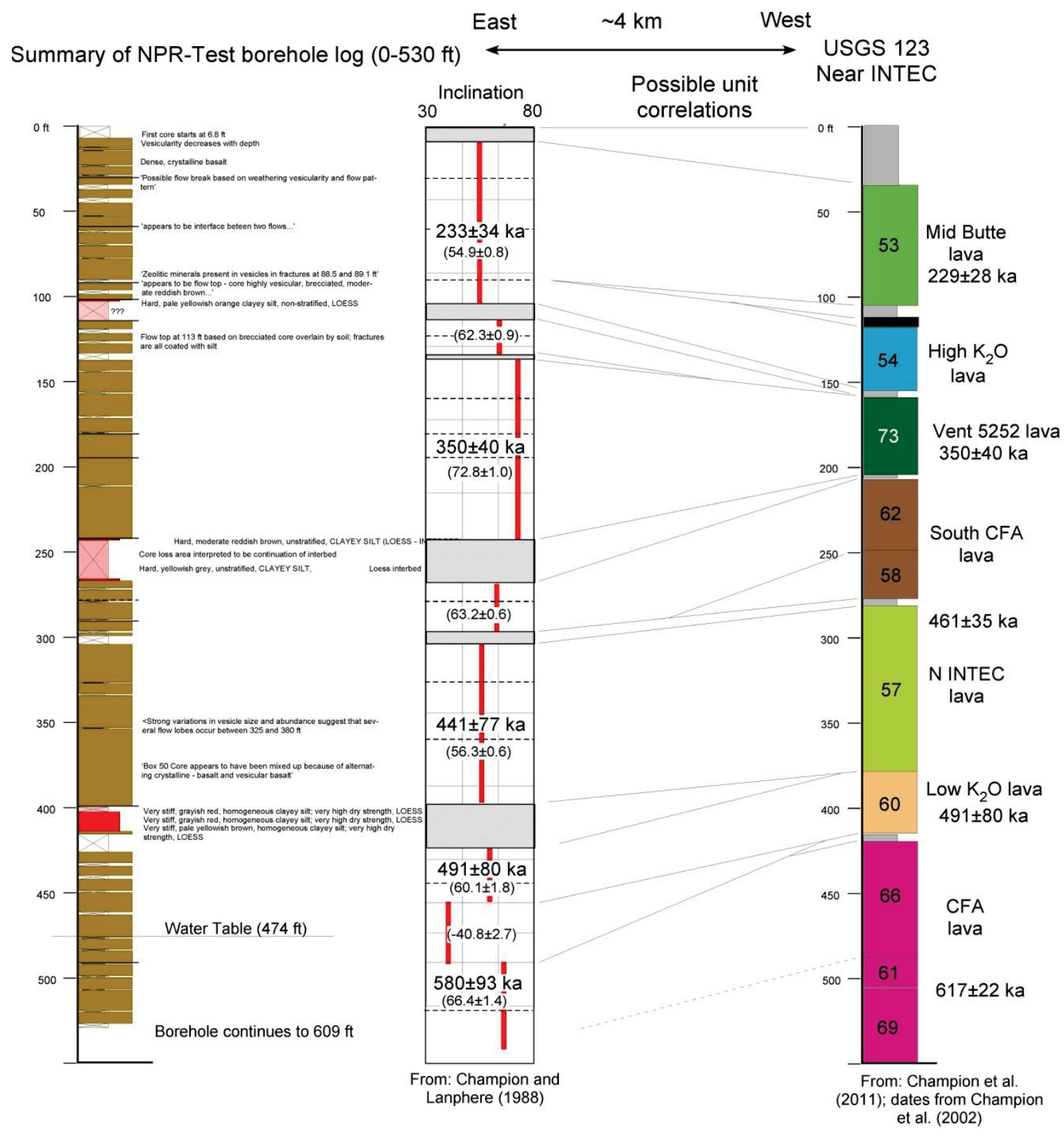

Figure 16. Borehole log of NPR-Test (source), and plausible correlations of stratigraphic units between NPR-Test and INTEC. 


\section{Nuclear Furnace Option}

In 1955, the Los Alamos Scientific Laboratory began the Rover program to develop a solid core nuclear rocket engine. The basic concept was to allow a graphite-fuel based nuclear reactor to reach high temperatures, to cool the reactor with clean hydrogen, and to exhaust the high-speed hydrogen for thrust. The advantages were seen to be shorter trip times, lower mass in orbit, and no possibility of accidental explosion.

In 1963, the Nuclear Engine for Rocket Vehicle Applications (NERVA) began with Aerojet as the prime contractor and Los Alamos as a supporting contributor. The goal of the NERVA program was to transform the nuclear reactor technology developed by Los Alamos and produce a space qualified nuclear engine. Both programs were terminated in 1972. Before termination, however, the Rover/NERVA programs built and tested 23 reactors/engines, achieved fuel temperatures in excess of $5500 \mathrm{~F}$, ran a reactor with a peak power of greater than 4000 megawatts, operated a system for over an hour, demonstrated start-up and shut-down operations, and proved that the graphite based reactor core could withstand the extreme conditions of operation. The exhaust of the engine in the final days of the program was calculated to have a specific impulse of near 850 seconds, almost three times the performance of the kerosene engines of the Saturn V and twice that of the soon-to-be-developed LOX/hydrogen engines of the Space Shuttle.

One of the issues that manifested later in the NERVA program was the high level of radioactivity present in the exhaust of the NTR. Because the fuel used a graphite matrix containing uranium carbide particles, the hot hydrogen in the coolant could chemically react through cracks in the cladding of the flow channels. Consequently, both uranium and fission products could escape nto the hydrogen flow and eject out the nozzle.

Around 1971, the Rover/NERVA programs demonstrated that the exhaust from a nuclear engine could be "scrubbed" clean of all fission products. As the result of increased restrictions on emission of radioactivity into the atmosphere, the Nuclear Furnace was built in order to continue testing new fuel-element materials. The Furnace consisted of a $45 \mathrm{MW}$ reactor in which many of the fuel elements could be replaced with experimental elements to assess behavior such as corrosion. The Nuclear Furnace reactor was followed by a sequence of filters to clean the effluent. After passing through the reactor, the hydrogen exhaust was sprayed with steam to cool 
the gas and remove any particulates. The flow then passed through a tube-and-kettle heat exchanger to further reduce the temperature. Next, the gas flowed through a silica gel bed to remove the water and any dissolved fission products. At this point, the only remaining products were the noble gases that were removed by passing the gases through a cryogenically cooled, activated charcoal bed. The result was a hydrogen jet that contained no detectable fission products.

Conceptually, a new nuclear furnace reactor could be built today to qualify NTR fuel elements. Then the first test of the NTR would be in space. Potentially, this could reduce program cost but adds program risk. To assess the possibility, difficulties, and ROM cost of building a nuclear furnace, the CSNR discussed the options and possibilities with expert INL staff. The funding level of this project was insufficient to subcontract the INL staff or perform any true cost estimates. The primary issues identified in the discussions were 1) need for a new Environmental Impact Statement, 2) physical security for a new, green-field construction near to existing facilities at the INL site, 3) ability to guarantee that no radioactivity was present in the exhaust, and 4) hydrogen handling and flaring. The reactor power was assumed to be the same as the Nuclear Furnace at 44 MWth. Given these assumptions and the fact that this would be a new Category I facility, the ROM estimate cost is in excess of $\$ 250 \mathrm{M}$. This estimate can be refined further and in more detail but further funding to the INL will be required.

\section{Conclusions}

The results show that the INL geology is substantially better suited to the SAFE testing method than the NTS site. The existence of impermeable interbeds just above the sub-surface aquifer ensure that no material from the test, radioactive or not, can enter the water table. Similar beds located just below the surface will prevent any gaseous products from reaching the surface for dispersion. The extremely high permeability of the strata between the interbeds allows rapid dispersion and dilution of the rocket exhaust. Preliminary gas transport calculations, and review of simulations performed for the NTS, indicate that condensation effects will not significantly increase backpressures above those calculated assuming isothermality. This suggests that the greater pressure diffusivity available in the INL subsurface could also allow the injection borehole to be significantly smaller diameter and the depth to be shallower than the holes at the NTS, which could substantially reduce project costs. In addition, the high permeability means a 
much lower back pressure in the hole against the rocket thrust which increases safety of operations. Finally, because of the highly permeability layered basalt and the presences of protective sedimentary interbeds at a shallow depth, cost of performing a sub-scale, non-nuclear verification experiment at the INL is was determined to be $\$ 2,100 \mathrm{~K}$. This cost estimate is based on the computation gas injection model and the favorable geology. The assements presented in this report indicates that the non nuclear test could be conducted at a much shallower depth than at the NTS and with a significantly smaller bore hole diameter.

\section{References}

\section{1-4 ntr benefits studies}

\section{5-7 NRC reports}

\section{Rocketdyne scrubber, Tom hill scrubber, Msfe scrubber}

Safe howe 1999, Safe DRI 2007 Safe howe 2010

Ackerman, D.J., 1991, Transmissivity of the Snake River Plain aquifer at the Idaho National Engineering Laboratory, Idaho: U. S. Geological Survey Scientific Investigations Report 91-4058, p. 35.

Anders, M.H., Geissman, J.W., Piety, L.A., and Sullivan, J.T., 1989, Parabolic distribution of circumeastern Snake River Plain seismicity and latest Quaternary faulting: Migratory pattern and association with the Yellowstone hotspot: Journal of Geophysical Research, v. 94, p. 1589-1621.

Anderson, S.R., and Bowers, B., 1995, Stratigraphy of the unsaturated zone and uppermost part of the Snake River Plain aquifer at Test Area North, Idaho National Engineering Laboratory, Idaho: U. S. Geological Survey Water-Resources Investigations Report 95-4130, p. 47.

Anderson, SR and MJ Liszewski, 1997, Stratigraphy of the unsaturated zone and the Snake River Plain aquifer at and neare the Idaho National Engineering Laboratory, Idaho. Idaho National Laboratory Report DOE/ID-22142, 65 p.

Bartholomay, R.C., Davis, L.C., Fisher, J.C., Tucker, B.J., and Raben, F.A., 2012, Water-Quality Characteristics and Trends for Selected Sites At and Near the Idaho National Laboratory, Idaho, 1949 - 2009: U. S. Geological Survey Scientific Investigations Report 2012-5169, p. 67.

Bestland, E.A., Link, P.K., Lanphere, M.A., and Champion, D.E., 2002, Paleoenvironments of sedimentary interbeds in the Pliocene and Quaternary Big Lost Trough (eastern Snake River Plain, Idaho): Geological Society of America Special Paper 353, p. 27-44.

Busenberg, E., Plummer, L.N., and Bartholomay, R.C., 2001, Estimated age and source of the young fraction of ground water at the Idaho National Engineering and Environmental Laboratory: U. S. Geological Survey Water-Resources Investigations Report, v. 2001-4265, p. 144. 
Cahn, Magnuson, Rood, Jolley (2008), Operable Unit 10-08 Sitewide Groundwater and Miscellaneous Sites Remedial Investigation/Baseline Risk Assessment, DOE/ID-11332.

Cooper, C.A., and D.L. Decker, 2011, Injection of nuclear rocket exhaust and water into a deep unsaturated zone, Nuclear Technology, 174(3), 452-459.

Champion, D.E., Hodges, M.K. V., Davis, L.C., and Lanphere, M.A., 2011, Paleomagnetic Correlation of Surface and Subsurface Basaltic Lava Flows and Flow Groups in the Southern Part of the Idaho National Laboratory, Idaho, with Pleomagnetic Data Tables for Drill Cores Scientific Investigations Report 2011 - 5a049: U. S. Geological Survey Scientific Investigations Report 20115049 , p. 33.

Champion, D.E., Lanphere, M.A., and Kuntz, M.A., 2002, Accumulation and subsidence of late Pleistocene basaltic lava flows of the eastern Snake River Plain, Idaho, in Link, P.K. and Mink, L.L. eds., Geology, Hydrogeology, and Environmental Remediation: Idaho National Engineering and Environmental Laboratory, Eastern Snake River Plain. Geological Society of America Special Paper, Geological Society of America, p. 175-192.

Davis, L.C., 2010, An Update of Hydrologic Conditions and Distribution of Selected Constituents in Water, Snake River Plain Aquifer and Perched Groundwater Zones, Idaho National Laboratory, Idaho , Emphasis 2006 - 08 Scientific Investigations Report 2010 - 5197: US Geological Survey Scientific Investagations Report 2010-5197, p. 94.

Dechert, T. V, Mcdaniel, P.A., Pierce, K.L., Falen, A.L., and Fosberg, M.A., 2006, Late Quaternary Stratigraphy, Idaho National Laboratory, Eastern Snake River Plain, Idaho: Idaho Geological Survey Technical Report 06-1, p. 19.

Fisher, J.C., Rousseau, J.P., Bartholomay, R.C., and Rattray, G.W., 2012, A Comparison of U . S . Geological Survey Three-Dimensional Model Estimates of Groundwater Source Areas and Velocities to Independently Derived Estimates, Idaho National Laboratory and Vicinity, Idaho Scientific Investigations Report 2012 - 5152: U. S. Geological Survey Scientific Investigations Report 2012-5152, p. 142.

Garabedian, S.P., 1992, Hydrology and digital simulation of the regional aquifer system, Eastern Snake River Plain: U. S. Geological Survey Professional Paper, v. 1408-F, 102 p.

Geslin, J.K., Link, P.K., Riesterer, J.W., Kuntz, M.A., and Fanning, C.M., 2002, Pliocene and Quaternary stratigraphic architecture and drainage systems of the Big Lost Trough, northeastern Snake River Plain, Idaho: Geological Society of America Special Paper 353, p. 11-26.

Hackett, WP, Smith, RP and S Khericha, 2002. Volcanic hazards of the Idaho National Engineering and Enviromental Laboratory, Southeast Idaho. In, B Bonnichsen, CM White and M McCurry, eds., Tectonic and Magmatic Evolution of the Snake River Plain Volcanic Province, Idaho Geological Survey Bulletin 30:461-482.

Hodges, M.K. V., Orr, S., Potter, K.E., and LeMaitre, T., 2012, Construction Diagrams, Geophysical Logs , and Lithologic Descriptions for boreholes USGS 103, 105, 108, 131, 135, NRF-15, and NRF-16, Idaho National Laboratory, Idaho: U. S. Geology Survey Data Series 660, p. 34. 
Holmes, A. a. J., Rodgers, D.W., and Hughes, S.S., 2008, Kinematic analysis of fractures in the Great Rift, Idaho: Implications for subsurface dike geometry, crustal extension, and magma dynamics: Journal of Geophysical Research, v. 113, no. B4, p. 1-15, doi: 10.1029/2006JB004782.

Hughes, S.S., Smith, R.P., Hackett, W.R., and Anderson, S.R.,1999, Mafic Volcanism and Environmental Geology of the Eastern Snake River Plain, Idaho, in Hughes, S.S., and Thackray, G.D., eds., Guidebook to the Geology of Eastern Idaho: Idaho Museum of Natural History, p. 143-168.

Hughes, S.S., P.H. Wetmore, and J.L. Casper, 2002, Evolution of Quaternary tholeiitic basalt eruptive centers on the eastern Snake River Plain, Idaho, in Bill Bonnichsen, C.M. White, and Michael McCurry, eds., Tectonic and Magmatic Evolution of the Snake River Plain Volcanic Province: Idaho Geological Survey Bulletin 30: 363-385.

Hughes, SS, McCurry, M and DJ Geist, 2002. Geochemical correlations and implications for the magmatic evolution of basalt flow groups at the Idaho National Engineering and Environmental Laboratory. in Link, P.K. and Mink, L.L. eds., Geology, Hydrogeology, and Environmental Remediation: Idaho National Engineering and Environmental Laboratory, Eastern Snake River Plain. Geological Society of America Special Paper, Geological Society of America, p. 151-174.

Jackson, S.M., Wong, I.G., Carpenter, G.S., Anderson, D.M., and Martin, S.M., 1993, Contemporary seismicity in the Eastern Snake River Plain, Idaho based on microearthquake monitoring: Bulletin of the Seismological Society of America, v. 83, no. 3, p. 680-695.

Jackson, S.M., Carpenter, G.S., Smith, R.P., and Casper, J.L., 2006, Seismic reflectionr project near the southern terminations of the Lost River and Lemhi Faults, Eastern Snake River Plain, Idaho: Idaho National Laboratory Report, v. INL/EXT-06, no. October, p. 16.

Kuntz, M.A., Anderson, S.R., Champion, D.E., Lanphere, M.A., and Grunwald, D.J., 2002, Tension cracks, eruptive fissures, dikes, and faults related to late Pleistocene-Holocene basaltic volcanism and implications for the distribution of hydraulic conductivity in the eastern Snake River Plain, Idaho: Geological Society of America Field Guide, v. 353, p. 111-133.

Kuntz, M.A., Skipp, B.A., Lanphere, M.A., Scott, W.E., Pierce, K.L., Dalrymple, G. B. Champion, D.E., Embree, G.F., Page, W.R., Morgan, L.A., Smith, R.P., Hackett, W.R., and Rodgers, D.W., 1994, Geologic map of the Idaho National Engineering Laboratory and adjoining areas, eastern Idaho: U. S. Geological Survey IMAP, v. 2330.

Kuntz, MA, Geslin, JK, Mark, LE, Hodges, MKV, Kauffman, ME, Champion, DE, Lanphere, MR, Rodgers, DW, Anders, MH, Link, PK and DL Boyack, 2003, Geologic map of the northern and central parts of the Idaho National Engineering and Environmental Laboratory, Eastern Idaho. Idaho Geological Survey Geologic Map 35. Internet reference:

http://www.idahogeology.org/PDF/Maps_(M)/Geologic_Maps_(GM)/PDF/TAN_GM-35-m.pdf

Magnuson, S., 2004, Regulatory Modeling for the Idaho National Engineering and Environmental Laboratory's Subsurface Disposal Area and Conceptual Model Uncertainty Treatment: Vadose Zone Journal, v. 3, no. 1, p. 59-74, doi: 10.2113/3.1.59. 
Magnuson, S.O and A.J. Sondrup, 2006, Subsurface Flow and Transport Model Development for the Operable Unit 7-13/14 Remedial Investigation and Feasibility Study, ICP/EXT-0501016.

McCurry, M., Hayden, K.P., Morse, L.H., and Mertzman, S., 2007, Genesis of post-hotspot, A-type rhyolite of the Eastern Snake River Plain volcanic field by extreme fractional crystallization of olivine tholeiite: Bulletin of Volcanology, v. 70, no. 3, p. 361-383, doi: 10.1007/s00445-007-01434.

Morse, L.H., 2002, Basalt alteration and authigenic mineralization near the effective base of the Snake River Plain aquifer at the idaho National Engineering and Environmental Laboratory, Idaho: Idaho State University.

Mudra, P.J and B.L. Schmalz, 1965, An Appraisal of Gaseous Waste Disposal into the Lithosphere at the National Reactor Testing Station, Idaho, IDO-12024.

North Wind, 2011, Idaho National Laboratory comprehensive land use and environmental stewarship report. Idaho National Laboratory Report INL/EXT-0500726, 71 p.

Ostenaa, DA, O'Connell, RH, Walter, RA and RJ Creed, 2002. Holocene paleoflood hydrology of the Big Lost River, western Idaho National Engineering and Environmental Laboratory, Idaho. in Link, P.K. and Mink, L.L. eds., Geology, Hydrogeology, and Environmental Remediation: Idaho National Engineering and Environmental Laboratory, Eastern Snake River Plain. Geological Society of America Special Paper, Geological Society of America, p. 91-110.

Payne, SJ, Carpenter, NS, Hodges, JM and RG Berg, 2009, INL seismic monitoring annual report: January 1, 2008 - December 31, 2008. Idaho National Laboratory Report INL/EXT-09-16687, 81 p.

Pierce, KL and LA Morgan, 1992. The track of the Yellowstone hot spot: volcanism, faulting, and uplift. In, Link, PK, Kuntz, MA and Platt, LB, eds., Regional Geology of Eastern Idaho and Western Wyoming: Geological Society of America Memoir 179: 1-53.

Pruess, K., C. Oldenburg, and G. Moridis, 1999, TOUGH2 User's Guide, Version 2.0, Report LBNL-43134, Lawrence Berkeley National Laboratory.Garabedian, S. P., 1992, "Hydrology and Digital Simulation of the Regional Aquifer System, Eastern Snake River Plain, Idaho," Professional Paper 1408-F, U.S. Geological Survey.

Robertson, J. B., 1974, Digital Modeling of Radioactive and Chemical Waste Transport in the Snake River Plain Aquifer at the National Reactor Testing Station, Idaho - 1952-1970, Open-File Report IDO-22054, U.S. Geological Survey.

Schmandt, B., Dueker, K., Humphreys, E., and Hansen, S., 2012, Hot mantle upwelling across the 660 beneath Yellowstone: Earth and Planetary Science Letters, v. 331-332, p. 224-236, doi: 10.1016/j.epsl.2012.03.025.

Smith, R.B., Jordan, M., Steinberger, B., Puskas, C.M., Farrell, J., Waite, G.P., Husen, S., Chang, W.-L., and O'Connell, R., 2009, Geodynamics of the Yellowstone hotspot and mantle plume: Seismic and GPS imaging, kinematics, and mantle flow: Journal of Volcanology and Geothermal Research, v. 188, no. 1-3, p. 26-56, doi: 10.1016/j.jvolgeores.2009.08.020. 
Smith, R.P., Jackson, S.M., and Hackett, W.R., 1996, Paleoseismology and seismic hazards evaluations in extensional volcanic terrains: Journal of Geophysical Research, v. 101, no. B3, p. 6277-6292.

Stroup, C.N., Welhan, J.A., and Davis, L.C., 2008, Statistical Stationarity of sediment interbed thicknesses in a basalt aquifer, Idaho National Laboratory, Eastern Snake River Plain, Idaho. U. S. Geological Survey Scientific Investigations Report 2008-5167.

Twining, B. V., Hodges, M.K. V., and Orr, S., 2008, Construction diagrams, geophysical logs, and lithologic descriptions for boreholes USGS 126a, 126b, 127, 128, 129, 130, 131, 132, 133, and 134, Idaho National Laboratory, Idaho: U. S. Department of Energy DOE/ID-222, p. 27.

Welhan, J.A., Johannesen, C.M., Reeves, K.S., Clemo, T.M., Glover, J.A., and Bosworth, K.W., 2002, Morphology of inflated pahoehoe lavas and spatial architecture of their porous and permeable zones , eastern Snake River Plain, Idaho: , p. 135-150.

Welhan, J.A., Farabaugh, R.L., Merrickj, M.J., and Anderson, S.R., 2006, Geostatistical Modeling of Sediment Abundance in a Heterogeneous Basalt Aquifer at the Idaho National Laboratory, Idaho Scientific Investigations Report 2006-5316: U. S. Geological Survey Scientific Investigations Report 2006-5316, p. 32.

Whitehead, RL, 1992, Geohyddrologic framework of the Snake River Plain regional aquifer system, Idaho and Eastern Oregon. U.S. Geological Survey Professional Paper 1408-B, 32 p.

Wood, T.R., Bates, D., Bishop, C.W., Heath, G.L., Hubbell, J.M., Hull, L.C., Lehman, R.M., Magnuson, S.O., Mattson, E.D., McCarthy, J.M., Porro, I., Ritter, P.D., Roddy, M., Sisson, J.B., et al., 2000, Deficiencies in vadose zone understanding at the Idaho National Engineering And Environmental Laboratory: Idaho National Engineering and Environmental Laboratory Bechtel BWXT Idahod, LLC Report, v. INEEL/EXT-, p. 191. 